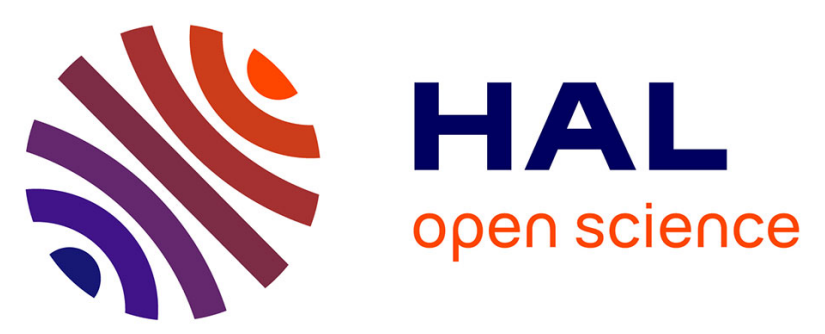

\title{
Rare Earth Metal Complexes Supported by Ancillary Imidazolin-2-iminato Ligands
}

\author{
Matthias Tamm, Alexandra G. Trambitas, Tarun K. Panda
}

\section{To cite this version:}

Matthias Tamm, Alexandra G. Trambitas, Tarun K. Panda. Rare Earth Metal Complexes Supported by Ancillary Imidazolin-2-iminato Ligands. Journal of Inorganic and General Chemistry / Zeitschrift für anorganische und allgemeine Chemie, 2010, 636 (12), pp.2156. 10.1002/zaac.201000224 . hal00599879

\section{HAL Id: hal-00599879 \\ https://hal.science/hal-00599879}

Submitted on 11 Jun 2011

HAL is a multi-disciplinary open access archive for the deposit and dissemination of scientific research documents, whether they are published or not. The documents may come from teaching and research institutions in France or abroad, or from public or private research centers.
L'archive ouverte pluridisciplinaire HAL, est destinée au dépôt et à la diffusion de documents scientifiques de niveau recherche, publiés ou non, émanant des établissements d'enseignement et de recherche français ou étrangers, des laboratoires publics ou privés. 


\section{Zeitschrift für Anorganische und} Allgemeine Chemie

\section{Rare Earth Metal Complexes Supported by Ancillary Imidazolin-2-iminato Ligands}

\begin{tabular}{|c|c|}
\hline Journal: & Zeitschrift für Anorganische und Allgemeine Chemie \\
\hline Manuscript ID: & zaac. 201000224.R1 \\
\hline Wiley - Manuscript type: & Research Report \\
\hline $\begin{array}{r}\text { Date Submitted by the } \\
\text { Author: }\end{array}$ & $10-J u n-2010$ \\
\hline Complete List of Authors: & $\begin{array}{l}\text { Tamm, Matthias; Technische Universität Braunschweig, Institut für } \\
\text { Anorganische und Analytische Chemie } \\
\text { Trambitas, Alexandra G.; Technische Universität Braunschweig, } \\
\text { Institut für Anorganische und Analytische Chemie } \\
\text { Panda, Tarun K.; Technische Universität Braunschweig, Institut für } \\
\text { Anorganische und Analytische Chemie }\end{array}$ \\
\hline Keywords: & $\begin{array}{l}\text { Rare earth metals, Lanthanides, Imidazolin-2-iminato ligands, Non- } \\
\text { cyclopentadienyl ligands, Homogeneous catalysis }\end{array}$ \\
\hline \multicolumn{2}{|c|}{$\begin{array}{l}\text { Note: The following files were submitted by the author for peer review, but cannot be converted } \\
\text { to PDF. You must view these files (e.g. movies) online. }\end{array}$} \\
\hline $\begin{array}{l}\text { Figure 1.cdx } \\
\text { Scheme 1.cdx } \\
\text { Scheme 10.cdx } \\
\text { Scheme 11.cdx } \\
\text { Scheme 12.cdx } \\
\text { Scheme 13.cdx } \\
\text { Scheme 14.cdx } \\
\text { Scheme 15.cdx } \\
\text { Scheme 16.cdx } \\
\text { Scheme 17.cdx } \\
\text { Scheme 18.cdx } \\
\text { Scheme 19.cdx } \\
\text { Scheme 2.cdx } \\
\text { Scheme 20.cdx } \\
\text { Scheme 3.cdx } \\
\text { Scheme 4.cdx } \\
\text { Scheme 5.cdx } \\
\text { Scheme 6.cdx } \\
\text { Scheme 7.cdx }\end{array}$ & \\
\hline
\end{tabular}


Scheme 8.cdx

Scheme 9.cdx

\section{5) ScholaroNE" \\ Manuscript Central}




\title{
Research Report
}

\section{Rare Earth Metal Complexes Supported by Ancillary}

\section{Imidazolin-2-iminato Ligands}

\author{
Alexandra G. Trambitas, ${ }^{[a]}$ Tarun K. Panda, ${ }^{[b]}$ and Matthias Tamm**a] \\ * Prof. Dr. M. Tamm \\ Fax: +49-531-391-5387 \\ E-Mail: m.tamm@tu-bs.de \\ [a] Institut für Anorganische und Analytische Chemie \\ Technische Universität Carolo-Wilhelmina \\ Hagenring 30, \\ D-38106 Braunschweig, Germany \\ [b] Indian Institute of Technology Hyderabad \\ Ordnance Factory Estate \\ Yeddumailaram 502205 \\ Andhra Pradesh, India
}




\section{Biographical Scetch}

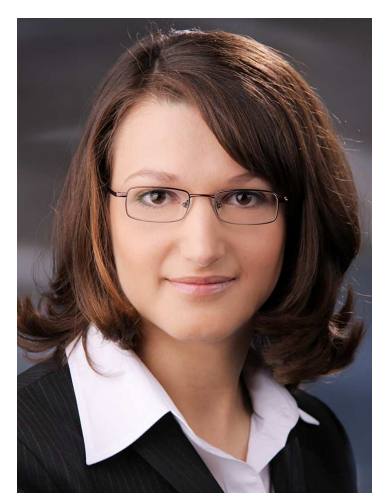

Alexandra G. Trambitas was born in Fagaras, Romania, in 1983 and studied chemistry at the “Babes-Bolyai” University, Cluj-Napoca, Romania. From 2004 to 2006, she was Erasmus Socrates student at the Technical University Braunschweig, where she prepared her diploma thesis at the Institute for Organic Chemistry under the guidance of Prof. Dr. Henning Hopf. After finishing her chemistry studies in Romania, she returned to Braunschweig to work towards her $\mathrm{PhD}$ at the Institute of Inorganic and Analytical Chemistry in the research group of Prof. Dr. Matthias Tamm. From 2007 - 2010, her research was financially supported through a scholarship from the Evonik Foundation. 


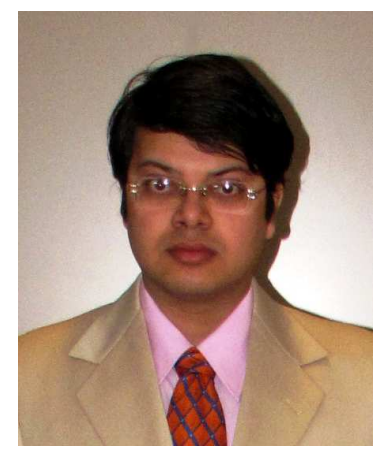

Tarun K. Panda was born in 1978 in India and obtained his B.Sc from the R. K. Mission Residential College, Narendrapur in 2000, affiliated with University of Calcutta, and M.Sc from IIT Kanpur in 2002. He joined the Freie Universität Berlin as a doctoral student under the supervision of Prof. Dr. Peter W. Roesky and received the title "Dr. rer. nat." in 2005. Dr. Panda worked as a post-doc with Prof. Dr. Matthias Tamm at the Technische Universität Braunschweig, Germany (2006-2007), and was awarded a postdoctoral fellowship from the Japan Society for the Promotion of Science (JSPS) to work with Prof. Kazushi Mashima at Osaka University, Japan (2008-2010). In May, 2010 he joined the Department of Chemistry at the Indian Institute of Technology, Hyderabad, India, as an Assistant Professor 


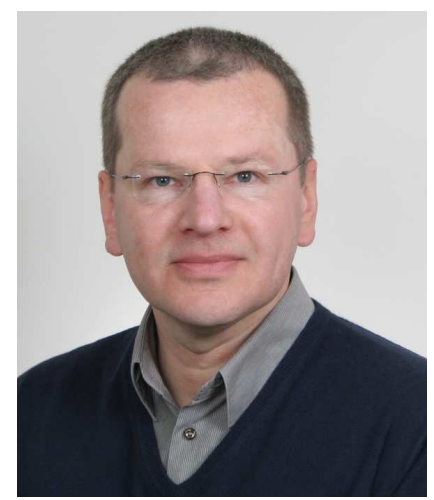

Matthias Tamm was born in Berlin, Germany, in 1967 and studied chemistry at the Technische Universität Berlin, where he received his $\mathrm{PhD}$ in 1992 under the supervision of $\mathrm{F}$. Ekkehardt Hahn. After spending one year as a Visiting Research Scientist at DuPont Central Research and Development, DE, USA with Anthony J. Arduengo, III, he returned to Germany in 1994 to complete his Habilitation in Berlin and Münster. Tamm was appointed to Privatdozent at the Westfälische Wilhelms-Universität Münster in 1999 and held a temporary professorship at the Technische Universität München from 2002 to 2005 . He then moved to the Technische Universität Carolo-Wilhelmina zu Braunschweig in 2005 to become full professor of inorganic chemistry. In 2009, he was offered a full professorship at the Freie Universität Berlin, which he declined. His research interests lie in the areas of preparative organometallic chemistry and coordination chemistry with an emphasis on the development of novel, unusual ligand systems and on the application of their transition metal complexes in homogeneous catalysis, organic synthesis and materials science. 


\begin{abstract}
The coordination chemistry of imidazolin-2-iminato ligands towards rare earth metals is reviewed. The structural characterisation of a large number of mono-, bis- and tris(imidazolin2-iminato) complexes - in most cases scandium, yttrium, gadolinium and lutetium complexes - reveals almost exclusively the formation of mononuclear complexes with very short metalnitrogen bonds, confirming the ability of imidazolin-2-iminato ligands to efficiently act as imido-type $2 \sigma, 4 \pi$-electron donors. In particular, mono(imidazolin-2-iminato) metal dichlorides proved to be excellent starting materials for the introduction of alkyl, amido, cyclopentadienyl, cyclooctatetraenyl and carboranyl ligands and also for the preparation of efficient pre-catalysts for ring-opening, hydroamination and hydrosilylation reactions, allowing to establish imidazolin-2-iminato ligands as novel valuable members of the growing family of ancillary ligands in organo rare earth metal and organolanthanide chemistry. In addition, the coordination chemistry of several imidazolin-2-imine-hybrid ligands such as cyclopentadienyl-imine and pincer-type diimine ligands is described, and the structural characterisation of the resulting complexes indicates that also neutral imidazolin-2-imines act as strong amido-type donor ligands towards rare earth metal ions.
\end{abstract}

\title{
Keywords
}

Rare earth metals; Lanthanides; Scandium; Yttrium; Lutetium; Imidazolin-2-iminato ligands; Non-cyclopentadienyl ligands; Homogeneous catalysis; 


\section{Introduction}

It was the serendipitous discovery of ferrocene, $\left[\left(\eta-\mathrm{C}_{5} \mathrm{H}_{5}\right)_{2} \mathrm{Fe}\right],{ }^{[1]}$ in 1951 and one year later the seminal elucidation of its sandwich-type structure by E. O. Fischer ${ }^{[2]}$ and G. Wilkinson $^{[3]}$ that not only triggered the remarkable development of modern organotransition metal chemistry, ${ }^{[4,5]}$ but also paved the way for the preparation of the first series of organolanthanide complexes, i. e. tris(cyclopentadienyl) complexes, [( $\left.\left.\eta^{5}-\mathrm{C}_{5} \mathrm{H}_{5}\right)_{3} \mathrm{M}\right]$, by Wilkinson and Birmingham in $1954 .{ }^{[6]}$ Ever since, the organometallic chemistry of the rare earth elements has been dominated by cyclopentadienyl ligands $(\mathrm{Cp})$ or related aromatic ligands. ${ }^{[7-14]}$ In recent years, however, research in this area has increasingly focussed on the development of alternative ligand sets, and a growing number of monoanionic heteroatom ligands that can be regarded as $\mathrm{Cp}$-analogous ligands because of their charge and steric requirements have been playing a key role in organolanthanide and organo rare earth metal chemistry. ${ }^{[15,16]}$ Anionic ligands are required to electrostatically balance the positive charge of the lanthanide ions, which tend to form rather ionic complexes due to the limited radial extension of the 4 f orbitals. ${ }^{[17]}$ Since these metals are among the largest in the periodic table ${ }^{[18]}$ sterically demanding ligands are useful for the isolation of soluble molecular species. The most important ancillary ligands are monodentate alkoxides $(\mathrm{OR})$, siloxides $\left(\mathrm{OSiR}_{3}\right)$, aryloxides $(\mathrm{OR}),{ }^{[19]}$ amides $\left(\mathrm{NR}_{2}\right),{ }^{[20]}$ and phosphoraneiminates $\left(\mathrm{NPR}_{3}\right)^{[21]}$ as well as polydentate ligands such as $\beta$-diketonates, ${ }^{[22]} \beta$-diketiminates, ${ }^{[23]}$ benzamidinates, ${ }^{[24]}$ aminotroponiminates, ${ }^{[25]}$ aminopyridinato, ${ }^{[26]}$ bis(phosphinimino)methanide ${ }^{[27]}$ and also other phosphanoamides. ${ }^{[28,29]}$ Figure 1 shows a selection of important ligands that have played an important role for the application of rare earth metal complexes in homogeneous catalysis and material science. 


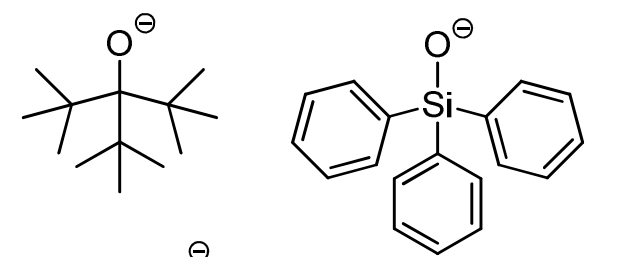<smiles>[R]c1cc([R])c([O-])c([R])c1</smiles><smiles>C[SiH2]N[SiH3]</smiles><smiles>[N-]=P(c1ccccc1)(c1ccccc1)c1ccccc1</smiles><smiles>[R]C(=O)C=C([R])[O-]</smiles><smiles>[R]N=C([R])C=C([R])N[R]</smiles><smiles>[R]N=c1cccccc1N[R]</smiles><smiles>[R][NH2+]c1ccccn1</smiles><smiles>C[SiH2]N=P(CP(=N[SiH3])(c1ccccc1)c1ccccc1)(c1ccccc1)c1ccccc1</smiles>

Figure 1. Selection of monoanionic ancillary ligands in rare earth metal chemistry.

\section{Imidazolin-2-iminato ligands}

Following several reports from N. Kuhn and co-workers, ${ }^{[30-32]}$ we have been able to introduce monoanionic imidazolin-2-iminato ligands $\left(\operatorname{Im}^{\mathrm{R}} \mathrm{N}, \mathbf{1 - R}\right)$ to the growing family of ancillary ligands and were able to demonstrate that these ligands are viable systems for the preparation of catalytically active transition as well as rare earth metal complexes. ${ }^{[33-43]}$ As terminal ligands, these systems correspond to phosphoraneiminato ligands $\left(\mathrm{NPR}_{3}\right)$, which were intensively investigated by Dehnicke et al. in both transition metal ${ }^{[44-46]}$ and rare earth metal chemistry. ${ }^{[21]}$ Thereby, Dehnicke proposed a bonding analogy between $\mathrm{Cp}$ and $\mathrm{NPR}_{3}$ ligands, since both are monoanionic ligands that can be regarded as $2 \sigma, 4 \pi$-electron donors. This pseudo-isolobal relationship can also be assigned to imidazolin-2-iminato ligands, in which the phosphine unit has been replaced by an N-heterocyclic carbene (Scheme 1). As indicated by the two limiting resonance structures $\mathbf{1 A}$ and $\mathbf{1 B}$, imidazolin-2-iminato ligands can either act as $2 \sigma, 2 \pi$-electron donors $(\mathbf{1 A})$ or as $2 \sigma, 4 \pi$-electron donors $(\mathbf{1 B})$, and the ability of the imidazolium ring to stabilise a positive charge affords highly basic ligands with a strong electron donating capacity toward early transition metals or metal in a higher oxidation state. $^{[47]}$ 
<smiles>[R]c1c([R])n([R])c(=N)n1[R]</smiles>

$1 \mathrm{~A}$

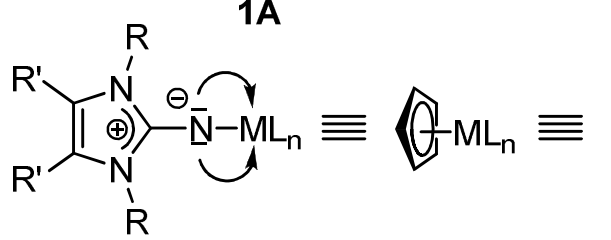

1B

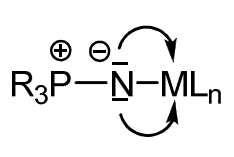

Scheme 1. Mesomeric structures for imidazolin-2-iminato complexes and isolobal realationship between imidazolin-2-iminato, cyclopentadienyl and phosphoraneiminato complexes.

In this report, we will cover the recent developments in the organometallic chemistry of rare earth metal complexes supported by imidazolin-2-iminato or imidazolin-2-imine-hybrid ligands. Moreover, the application of the resulting complexes in different areas of homogeneous catalysis will be presented. As representatives of the rare earth metals, the elements scandium, yttrium, lutetium and gadolinium were generally chosen, since their different ionic radii cover a large spectrum of different reactivities and coordination modes. ${ }^{[18]}$

\section{Mono(imidazolin-2-iminato) rare earth metal complexes}

\subsection{Dichloro complexes}

The entry into the organolanthanide complexes supported by imidazolin-2-iminato was accomplished by the synthesis of dichloro complexes of the type $\left[\left(\operatorname{Im}^{\text {Dipp }} \mathrm{N}\right) \mathrm{MCl}_{2}(\mathrm{THF})_{3}\right](\mathbf{2} \mathbf{a}$, $\mathrm{M}=\mathrm{Sc} ; \mathbf{2} \mathbf{b}, \mathrm{M}=\mathrm{Lu} ; \mathbf{2 c}, \mathrm{M}=\mathrm{Y})$ and of the "ate" complex $\left[\left(\mathrm{Im}^{\text {Dipp }} \mathrm{N}\right) \mathrm{GdCl}_{2}(\mathrm{THF})_{2}\right] \cdot\left[\mathrm{LiCl}(\mathrm{THF})_{2}\right](\mathbf{2 d}) \cdot{ }^{[41,42]}$ These complexes could be conveniently prepared by the reaction of the imine $\operatorname{Im}{ }^{\text {Dipp }} \mathrm{NH}$ (Dipp = 2,6-diisopropylphenyl) with trimethylsilylmethyl lithium $\left(\mathrm{LiCH}_{2} \mathrm{SiMe}_{3}\right)$ in the presence of the appropriate anhydrous rare 
earth metal halide $\mathrm{LnCl}_{3}(\mathrm{M}=\mathrm{Sc}, \mathrm{Y}, \mathrm{Lu}, \mathrm{Gd})$ and were isolated as colourless crystalline solids in good yield after crystallization from THF/pentane solutions (Scheme 2).

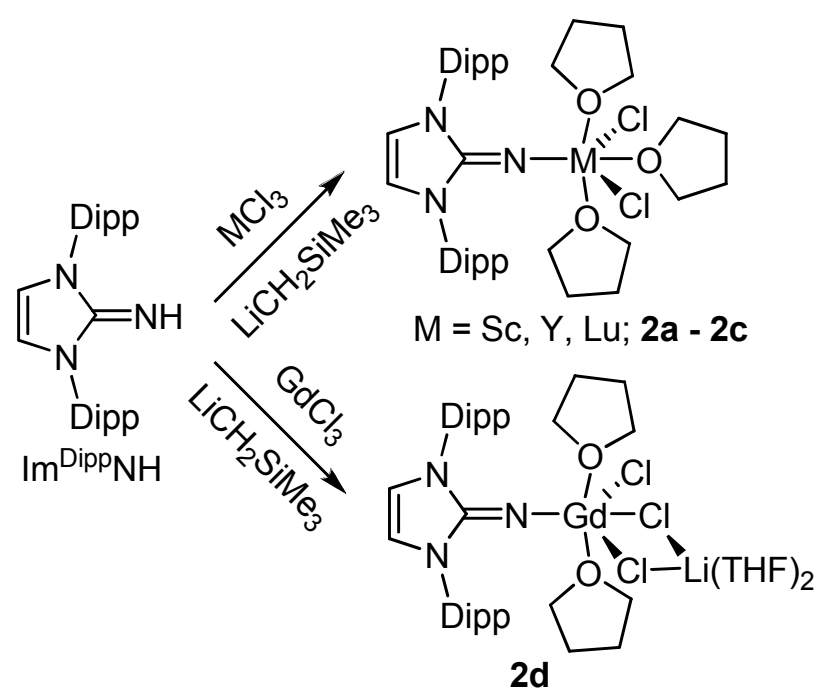

Scheme 2. Preparation of the imidazolin-2-iminato rare earth metal dichlorides 2.

The molecular structures of $\mathbf{2 a}$ - $\mathbf{2 d}$ were established by X-ray diffraction analyses; as a representative, the molecular structures of the scandium complex $\mathbf{2 a}$ is shown in Figure 2 . The solid state structures of compounds $\mathbf{2 a}-\mathbf{2 c}$ show a pseudo-octahedral coordination geometry around the rare earth metal atom with the two chloride ligands in trans-positions and the three THF ligands adopting a meridional arrangement, which corresponds to the mer-transconfiguration commonly observed for mono-Cp rare earth metal complexes. ${ }^{[10]}$ In all cases, exceptionally short metal-nitrogen bonds together with almost linear M-N1-C1 angles are observed (Table 1). At the time of publication, ${ }^{[41,42]}$ there was only one complex featuring a shorter Sc-N bond length, and that is the $\mathrm{AlMe}_{3}$ adduct of the recently reported transient scandium-imido complex [(PNP)Sc(N-Dipp)] containing the PNP pincer ligand bis(2diisopropylphosphino-4-methylphenyl)amide. ${ }^{[48]}$ The only other Sc-N bond lengths that featured bond lengths shorter than two angstroms have been reported for $\beta$-diketiminato complexes $[($ nacnac $) \operatorname{ScCl}(\mathrm{NH} t \mathrm{Bu})]$ and $\left[(\right.$ nacnac $\left.) \operatorname{Sc}\left(\mathrm{CH}_{3}\right)(\mathrm{NH} t \mathrm{Bu})\right] \cdot \mathrm{B}\left(\mathrm{C}_{6} \mathrm{~F}_{5}\right)_{3}$ with nacnac $=$ $[\mathrm{Dipp}-\mathrm{NC}(\mathrm{tBu}) \mathrm{CHC}(\mathrm{tBu}) \mathrm{N}-\mathrm{Dipp}] .{ }^{[49]}$ The metal-nitrogen bond length in $\mathbf{2} \mathbf{b}$ was also the 
second shortest reported for yttrium complexes at that time; and the shortest value was observed in a tetranuclear cyclopentadienyl-yttrium complex containing $\mu_{3}$-ethylimido ligands. ${ }^{[50]}$ Short Y-N distances have also been reported for yttrium-phosphoraneiminato complexes. ${ }^{[51]}$ The Lu-N bond length in $\mathbf{2 c}$ was still the shortest ever observed for lutetium complexes, and the previous shortest $\mathrm{Lu}-\mathrm{N}$ distances were found in benzamidinate and amido complexes. ${ }^{[50,52]}$ In the mean time, we have obtained several complexes, in which even shorter metal-nitrogen bonds are observed, thus giving further evidence for a particularly strong metal-ligand interaction in imidazolin-2-iminato complexes (vide infra, Table 1).

The molecular structure of $\mathbf{2 d}$ reveals that the trans-coordinated THF ligand in $\mathbf{2 a}-\mathbf{2} \mathbf{c}$ has been replaced by a chlorine atom $(\mathrm{Cl} 2)$. The resulting negative charge is neutralised by a $\left[\mathrm{Li}(\mathrm{THF})_{2}\right]^{+}$moiety, capping the chlorine atoms $\mathrm{Cl} 1$ and $\mathrm{Cl} 2$. Again the $\mathrm{Gd}-\mathrm{N} 1$ distance is very short, being the shortest value ever reported for gadolinium-nitrogen systems. The previous shortest Gd-N distances were observed for five-membered amidolanthanide heterocycles. $^{[53]}$

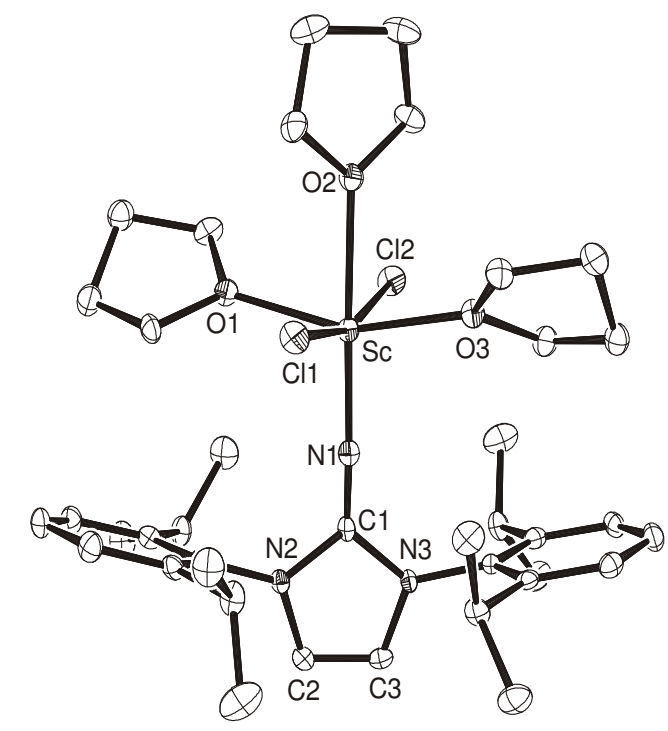

Figure 2. ORTEP diagrams of $\mathbf{2 a}$ and $\mathbf{2 d}$ with thermal displacement parameters drawn at 50\% probability; the two THF ligands coordinated to lithium in $\mathbf{2 d}$ are disordered.

Since the substituents on the imidazole heterocycle can easily be varied, numerous imidazolin-2-iminato ligands are available. ${ }^{[4]}$ Following the encouraging results obtained by 
using $\operatorname{Im}^{\text {Dipp }} \mathrm{N}$ to synthesize the dichloro complexes $\mathbf{2 a} \mathbf{- 2}$, the synthesis and structural characterisation of the yttrium complex $\left[\left(\mathrm{Im}^{t \mathrm{Bu}} \mathrm{N}\right) \mathrm{YCl}_{2}(\mathrm{THF})_{3}\right](3)$ was also achieved (Scheme 3). ${ }^{[54]}$ The overall structural parameters are very similar to those reported for the related complexes $2 \mathbf{a}-\mathbf{2 c}$. The metal atom is hexacoordinated with the two chlorine atoms in transposition and the three THF ligands adopting a meridional arrangement. The N1-Y interaction in 3, revealed by a very short Y-N1 bond length of $2.115(2) \AA$ (Table 1 ), is even slightly stronger than that observed for the corresponding $\operatorname{Im}^{\text {Dipp }} \mathrm{N}$ complex $2 \mathbf{c}\left[2.1278(18) \AA{ }^{[42]}\right.$

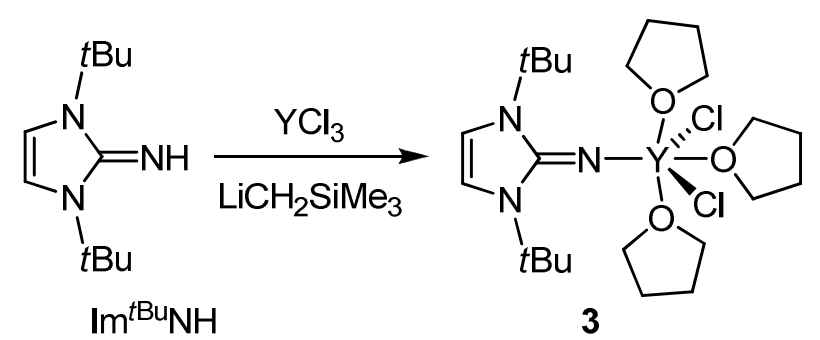

Scheme 3. Preparation of the yttrium dichloro complex $\left[\left(\operatorname{Im}^{\mathrm{tBu}} \mathrm{N}\right) \mathrm{YCl}_{2}(\mathrm{THF})_{3}\right](3)$.

\subsection{Bis(neosilyl) complexes}

In most cases, bis(neosilyl) rare earth metal complexes have been prepared by the reaction of $\left[\mathrm{M}\left(\mathrm{CH}_{2} \mathrm{SiMe}_{3}\right)_{3}(\mathrm{THF})_{2}\right]$ with the protonated form of a desired ancillary ligand, which is accompanied by release of tetramethylsilane (TMS). ${ }^{[55-58]}$ In our hands, however, the dichloro complexes 2 proved to be superior starting materials, and their reaction with two equivalents of $\mathrm{LiCH}_{2} \mathrm{SiMe}_{3}$ afforded the bis(neosilyl) complexes [( $\left.\left.\mathrm{Im}^{\mathrm{Dipp}} \mathrm{N}\right) \mathrm{Sc}\left(\mathrm{CH}_{2} \mathrm{SiMe}_{3}\right)_{2}(\mathrm{THF})\right](\mathbf{4 a})$, $\left[\left(\mathrm{Im}^{\mathrm{Dipp}} \mathrm{N}\right) \mathrm{M}\left(\mathrm{CH}_{2} \mathrm{SiMe}_{3}\right)_{2}(\mathrm{THF})_{2}\right](\mathbf{4 b}, \mathrm{M}=\mathrm{Y} ; \mathbf{4 c}, \mathrm{M}=\mathrm{Lu})$, and $\left[\left(\mathrm{Im}^{\mathrm{Dipp}} \mathrm{N}\right) \mathrm{Gd}\left(\mathrm{CH}_{2} \mathrm{SiMe}_{3}\right)_{2}(\mathrm{THF})_{2}\right](\mathbf{4 d})$ in high yields (Scheme 4$) .{ }^{[43]}$

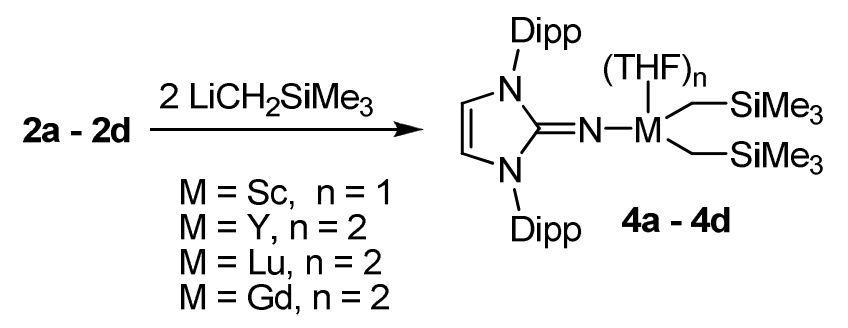

Scheme 4. Synthesis of the bis(neosilyl) complexes 4 . 

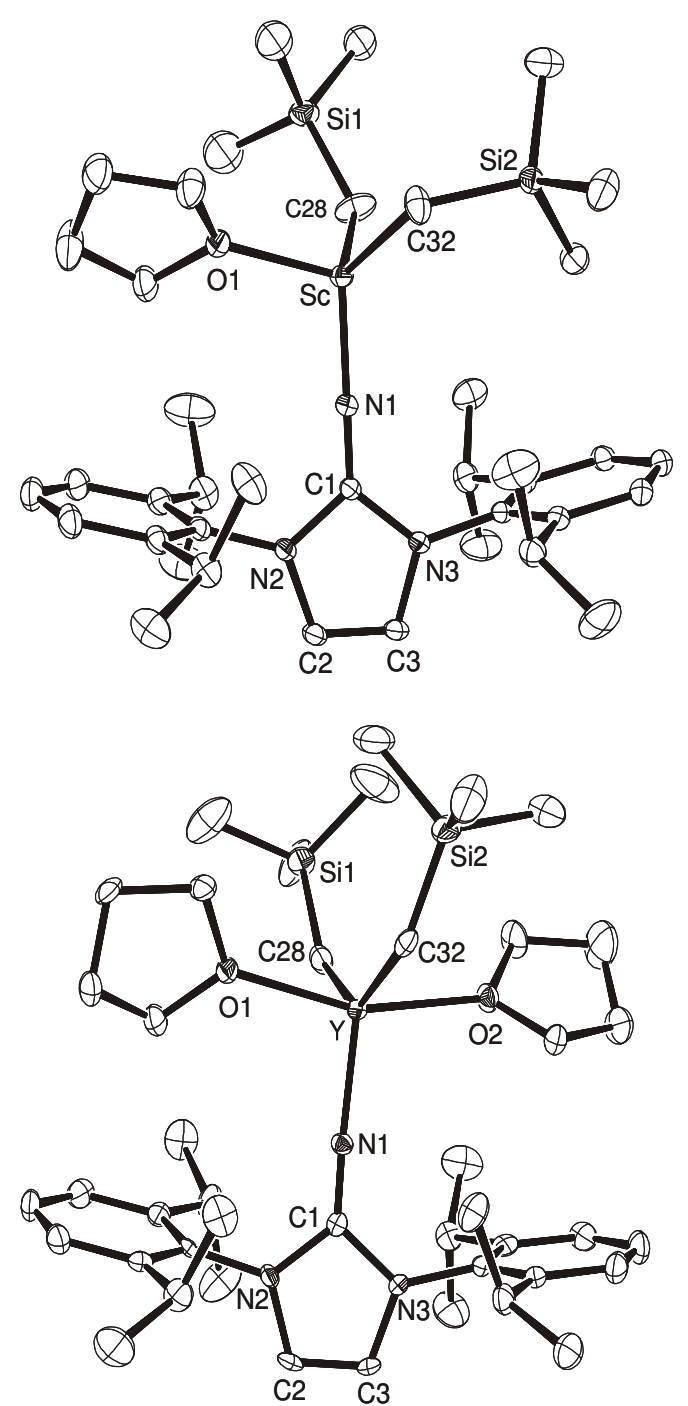

Figure 3. ORTEP diagram of $\mathbf{4 a}$ (top) and $\mathbf{4 b}$ (bottom) with thermal displacement parameters drawn at $50 \%$ probability.

The solid state structures of complexes $\mathbf{4 a}$ - $\mathbf{4 d}$ were determined by X-ray diffraction analyses. Since scandium has the smallest ionic radius of all rare earth elements, ${ }^{[18]}$ the metal atom in $\mathbf{4 a}$ is only four-coordinate and displays a strongly distorted tetrahedral coordination sphere (Figure 3). The imidazolin-2-iminato ligand coordinates in an almost perfectly linear fashion, and the Sc-N bond length is even shorter than observed for the dichloride $2 \mathbf{a}$ (Table 1). ${ }^{[40]}$ In contrast, complexes $\mathbf{4 b}, \mathbf{4 c}$ and $\mathbf{4 d}$ exhibit a five-coordinate metal atom with a trigonal-bipyramidal coordination sphere, in which the THF ligands adopt the axial positions, albeit with a pronounced deviation of the O1-M-O2 angles from $180^{\circ}$ (Figure 3). ${ }^{[43]}$ In 
addition, the yttrium and lutetium complexes $\mathbf{4 b}$ and $\mathbf{4 c}$ are isostructural, and both exhibit $\mathbf{M -}$ $\mathrm{N}$ bonds that are shorter than those found in the starting materials $\mathbf{2 b}-\mathbf{2} \mathbf{c}$ (Table 1). Complex 4b was additionally characterized by ${ }^{89} \mathrm{Y}$ NMR spectroscopy, showing a resonance at 813.8 ppm, which is up-field from the resonance at $882.7 \mathrm{ppm}$ reported for $\left[\mathrm{Y}\left(\mathrm{CH}_{2} \mathrm{SiMe}_{3}\right)_{3}(\mathrm{THF})_{2}\right]{ }^{[59]}$ This high-field shift is in agreement with the trend derived for other yttrium complexes upon substitution of alkyl groups by $\pi$-donor ligands. ${ }^{[60]}$

\subsection{Bis(amide) complexes}

In a similar fashion as described for bis(neosilyl) rare earth metal complexes, related diamido complexes are usually prepared from the triamides $\left[\mathrm{M}\left\{\mathrm{N}\left(\mathrm{SiRMe}_{2}\right)_{2}\right\}_{3}(\mathrm{THF})_{2}\right](\mathrm{R}=$ $\mathrm{Me}, \mathrm{H})$, which release one amine $\mathrm{HN}\left(\mathrm{SiRMe}_{2}\right)_{2}$ upon treatment with the protonated form of an appropriate ancillary ligand. ${ }^{[61]}$ Again, the reaction of the dichlorides $\mathbf{2 a} \mathbf{- 2 d}$ with two equivalents of $\left[\mathrm{Na}\left\{\mathrm{N}\left(\mathrm{SiMe}_{3}\right)_{2}\right\}\right]$ in THF proved to be a superior method, and the complexes 5a - 5d of the composition $\left[\left(\operatorname{Im}^{\text {Dipp }} \mathrm{N}\right) \mathrm{M}(\mathrm{HMDS})_{2}(\mathrm{THF})\right][\mathrm{HMDS}=$ hexamethyldisilazide, $\left.\mathrm{N}\left(\mathrm{SiMe}_{3}\right)_{2}\right]$ could be isolated (Scheme 5). ${ }^{[43]}$

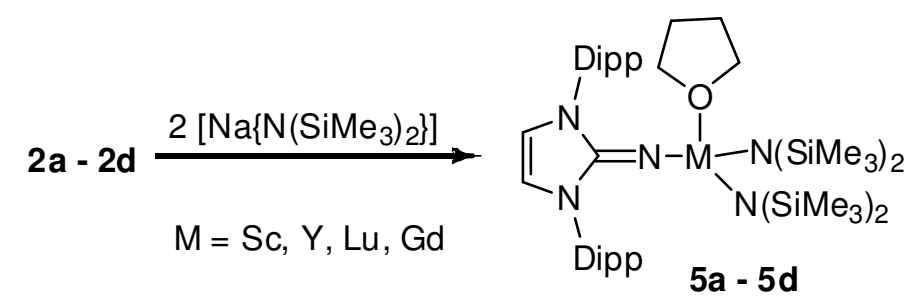

Scheme 5. Preparation of the diamido complexes 5a.

The X-ray crystal structures of the yttrium and gadolinium complexes $\mathbf{5 b}$ and $\mathbf{5 d}$ could be determined; in both cases, the coordination spheres around the metal atoms could be described as distorted tetrahedral geometries by coordination of one imidazolin-2-iminato ligand, two bis(trimethylsilyl)amido groups and one THF molecule. However, in both cases, 
short intramolecular C-H $\cdots \mathrm{M}$ contacts are observed with the methyl groups of one HMDS ligand as commonly found for related silylamido rare earth metal complexes (Figure 4). Since the methyl groups involved in these weak agostic interactions are located trans to the THF ligand, the metal coordination spheres in $\mathbf{5 b}$ and $\mathbf{5 d}$ should preferably be described as distorted trigonal-bipyramidal with the nitrogen ligands adopting the equatorial positions. As expected, the imidazolin-2-iminato ligands exhibit significantly shorter metal-nitrogen distances in comparison with the HMDS ligands, however, they are slightly longer than those found for the neosilyl complexes $\mathbf{4 b}$ and $\mathbf{4 d}$ (Table 1).

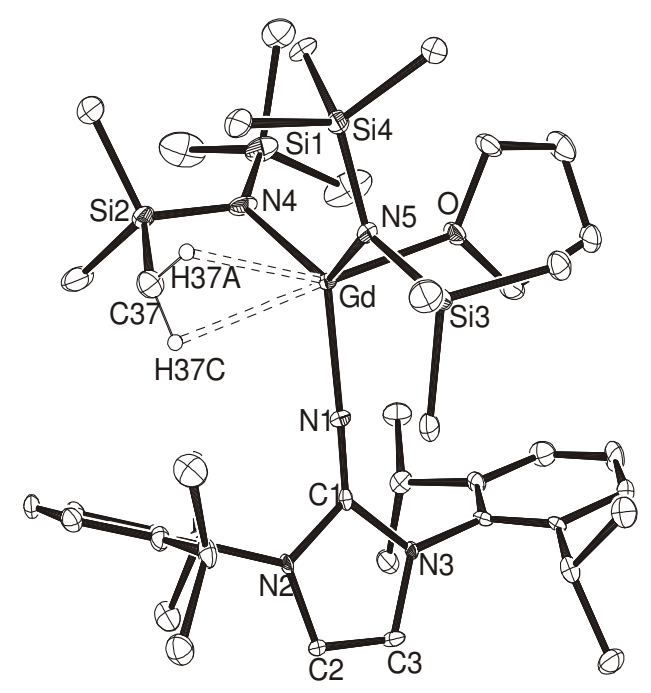

Figure 4. ORTEP diagram of $\mathbf{5 d}$ with thermal displacement parameters drawn at $50 \%$ probability.

\subsection{Bis(benzyl) complexes}

Benzyl $\left(\mathrm{CH}_{2} \mathrm{Ph}\right)$ complexes are also very common in organolanthanide chemistry and are often encountered as pre-catalysts in various rare earth metal catalyzed organic transformations, ${ }^{[62]}$ and therefore, the possibility to introduce benzyl ligands was tested for the lutetium dichloride $\mathbf{2 c}$ as an alternative for the established preparation from tribenzyl complexes of the type $\left[\mathrm{M}\left(\mathrm{CH}_{2} \mathrm{Ph}\right)_{3}(\mathrm{THF})_{\mathrm{n}}\right] \cdot{ }^{[63]}$ Accordingly, the bis(benzyl) complex $\mathbf{6 c}$ was synthesised by treatment of $\mathbf{2} \mathbf{c}$ with two equivalents of potassium benzyl $\left(\mathrm{KCH}_{2} \mathrm{Ph}\right)(\mathrm{Scheme}$ 
6). In a similar fashion as described for complexes $\mathbf{4 b}$ - $\mathbf{4 d}$ (vide supra), the solid state

structure of $\mathbf{6 c}$ reveals a five-coordinate lutetium metal, with the ligands forming a distorted trigonal-bipyramidal coordination sphere (Figure 5). The two benzyl ligands are coordinated in a monohapto fashion, whereas the $\mathrm{O} 1-\mathrm{Lu}-\mathrm{O} 2$ angle of $155.82(6)^{\circ}$ deviates significantly from a linear orientation, which can be mainly attributed to the steric demand of the diisopropylphenyl substituents of the imidazolin-2-iminato ligand. This ligand coordinates to the lutetium atom in an almost linear fashion with a very short Lu-N1 bond of 2.0752(18) $\AA$, which even falls below the values found for $\mathbf{2 c}$ and $\mathbf{4 c}$ (Table 1).

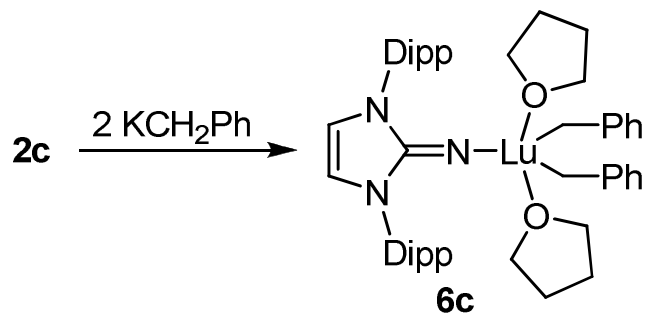

Scheme 6. Preparation of bis(benzyl) complex $\left[\left(\mathrm{Im}^{\mathrm{Dipp}} \mathrm{N}\right) \mathrm{Lu}\left(\mathrm{CH}_{2} \mathrm{Ph}\right)_{2}(\mathrm{THF})_{2}\right](\mathbf{6 c})$.

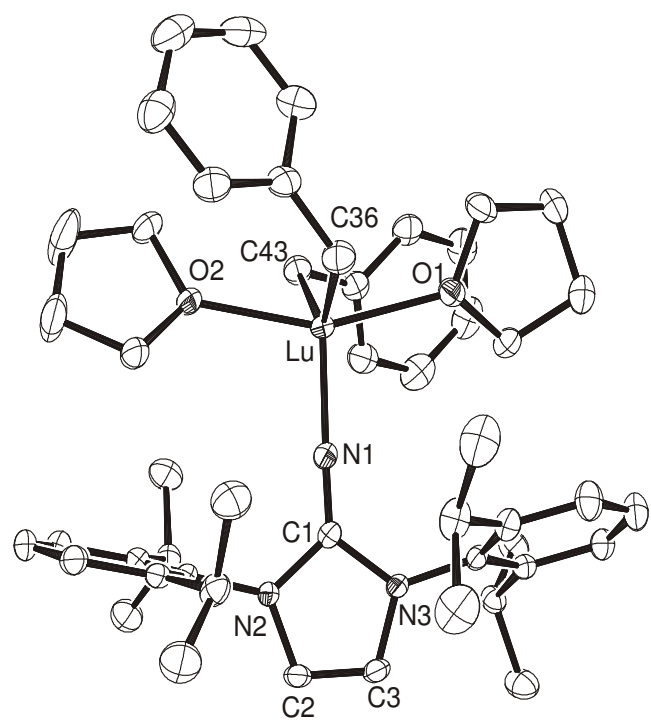

Figure 5. ORTEP diagram of $\mathbf{6 c}$ with thermal displacement parameters drawn at 50\% probability. 


\subsection{Pentamethylcyclopentadienyl complexes}

In view of the isolobal relationship between imidazolin-2-iminato and cyclopentadienyl (Cp) ligands (vide supra), the reaction of the dichlorides $\mathbf{2 a}-\mathbf{2 d}$ with pentamethylcyclopentadienyl potassium ( $\mathrm{KCp}^{*}$ ) was also pursued. In order to introduce two $\mathrm{Cp}^{*}$ ligands, the complexes 2 were treated with two equivalents of $\mathrm{KCp}^{*} \cdot{ }^{[43]}$ However, the spectroscopic characterisation indicated the formation of mono(pentamethylcyclopentadienyl) complexes $\left[\left(\mathrm{Im}^{\text {Dipp }} \mathrm{N}\right) \operatorname{Sc}(\mathrm{Cp} *) \mathrm{Cl}(\mathrm{THF})\right](\mathbf{7 a}),\left[\left(\mathrm{Im}^{\text {Dipp }} \mathrm{N}\right) \mathrm{Y}\left(\mathrm{Cp}^{*}\right) \mathrm{Cl}(\mathrm{THF})_{2}\right](\mathbf{7 b})$, and $\left[\left(\mathrm{Im}^{\mathrm{Dipp}} \mathrm{N}\right) \mathrm{Lu}\left(\mathrm{Cp}^{*}\right) \mathrm{Cl}(\mathrm{THF})\right](\mathbf{7 c})$. In contrast, the elemental analysis of the product, obtained from the reaction of $\mathbf{2 d}$ with two equivalents of $\mathrm{KCp}^{*}$, revealed that $\left[\left(\operatorname{Im}^{\text {Dipp }} \mathrm{N}\right) \mathrm{Gd}\left(\mathrm{Cp}^{*}\right)_{2}(\mathrm{THF})\right](\mathbf{8})$ has formed and that the larger gadolinium ion is able to accommodate two $\mathrm{Cp}^{*}$ ligands (Scheme 7). ${ }^{[43]}$

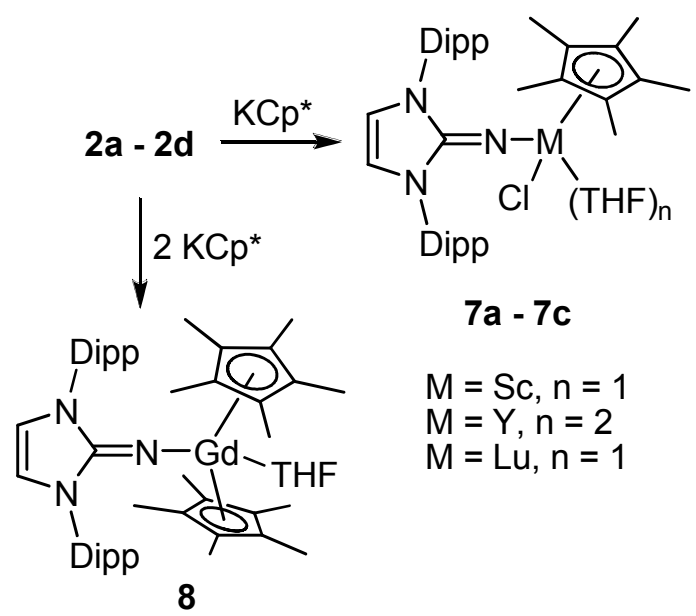

Scheme 7. Synthesis of the pentamethylcyclopentadienyl complexes $7 \mathbf{a}-7 \mathbf{c}$ and 8 .

The ${ }^{1} \mathrm{H}$ NMR spectra of the scandium and lutetium complexes $\mathbf{7 a}$ and $\mathbf{7 c}$ are very similar, indicating the coordination of just one sterically demanding $\mathrm{Cp}^{*}$ ligand and one THF ligand. In both complexes, the THF ligand gives rise to three resonances (two for the $\alpha$-H's and one for the $\beta$-H's), indicating a non-fluxional behaviour and strong coordination to the metal atom, which results in the formation of configurationally stable, chiral-at-metal complexes. ${ }^{[64]}$ Consequently, the non-fluxional behaviour has an impact also on the Dipp substituents and therefore the ${ }^{1} \mathrm{H}$ and ${ }^{13} \mathrm{C}$ NMR exhibits two signals for the diastereotopic isopropyl groups as 
well as two signals for the carbon atoms in the ortho and meta positions contained in the phenyl rests. In contrast, the spectroscopic characterisation of $\mathbf{7 b}$ indicates the coordination of a second THF ligand, and a doubling of the signals is not observed. It should be noted, however, that the resonances assigned to the isopropyl group are rather broad at room temperature, suggesting a higher fluxionality of the yttrium system $\mathbf{7 b}$ on the NMR time scale.

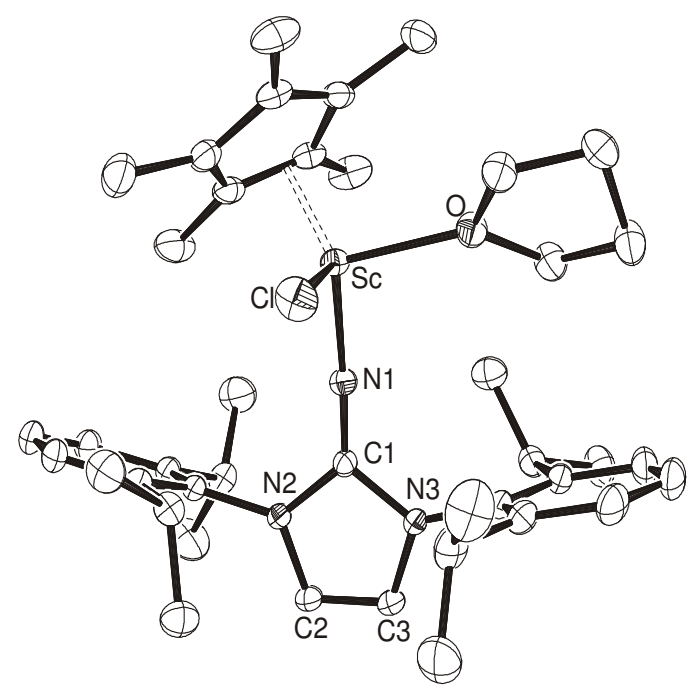

Figure 6. ORTEP diagram of 7a and $\mathbf{8}$ with thermal displacement parameters drawn at $50 \%$ probability.

The molecular structure of $\mathbf{7 a}$ and $\mathbf{7 c}$ deduced from the NMR spectroscopy could be additionally established by single-crystal X-Ray diffraction analysis (Figure 6), revealing a pseudo-tetrahedral geometry around the metal atoms ( $\mathrm{Sc}$ and $\mathrm{Lu}$ ). Yet again, the Sc-N and Lu-N bond lengths of 1.9575(10) and 2.0697(18) $\AA$ are very short (Table 1). The highly paramagnetic nature of the gadolinium complexes prohibited the use of NMR spectroscopy for the characterisation of $\mathbf{8}$; however, its solid state structure could be established by X-ray diffraction, confirming that a complex with two $\mathrm{Cp}^{*}$ ligands had formed. The coordination sphere around the Gd atom is completed by the imidazolin-2-iminato and one THF ligand to afford a distorted pseudo-tetrahedral geometry. The presence of two bulky $\mathrm{Cp}$ * rings leads to an elongation of the Gd-N bond length [2.2388(13) $\AA$ ] in comparison with the previously 
described imidazolin-2-iminato gadolinium complexes such as $\mathbf{2 d}, \mathbf{4 d}, \mathbf{5 d}$ (vide supra), and $\left[\left(\mathrm{Im}^{\mathrm{Dipp}} \mathrm{N}\right) \mathrm{Gd}\left(\eta^{8}-\mathrm{C}_{8} \mathrm{H}_{8}\right)(\mathrm{THF})_{2}\right]($ vine infra $) .{ }^{[42]}$

\subsection{Carboranyl complexes}

Despite the charge difference between monoanionic cyclopentadienyl ligands and dicarbollide dianions, the latter ones seem to be additional candidates for the development of a cyclopentadienyl-free rare earth metal chemistry. ${ }^{[65-67]}$ Such metal/charge combinations would have an impact on the properties of the resultant metal complexes. With this in mind, and in collaboration with the group of $\mathrm{Z}$. Xie,${ }^{[68-79]}$ we aimed at the synthesis of imidazolin-2iminato rare earth metal complexes bearing additional carboranyl ligands. Two synthetic methods, the salt metathesis route and the acid-base approach were examined. ${ }^{[80]}$

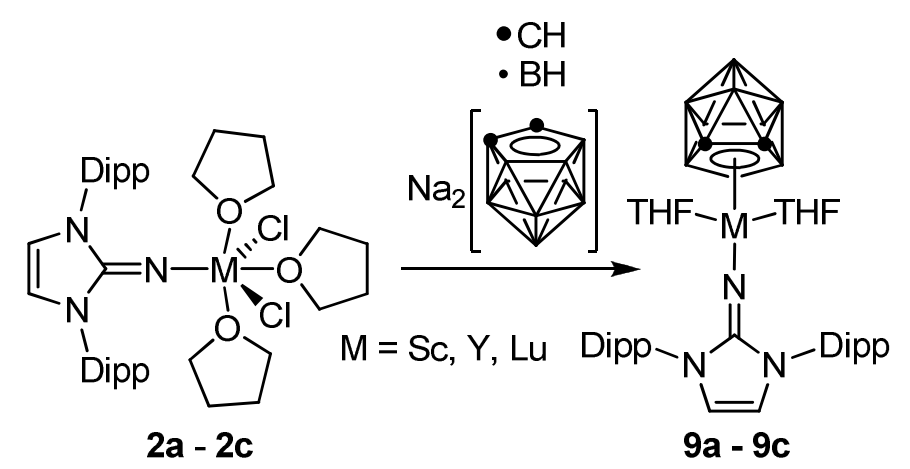

Scheme 8. Synthesis of the carboranyl complexes 9a - 9c through the salt metathesis route.

Scheme 8 shows the salt metathesis reaction between the dichlorides $\mathbf{2 a}-\mathbf{2} \mathbf{c}$ and the sodium salt $\mathrm{Na}_{2}\left(\mathrm{C}_{2} \mathrm{~B}_{9} \mathrm{H}_{11}\right),{ }^{[66]}$ which proceeds cleanly at $60{ }^{\circ} \mathrm{C}$ in THF solution to afford the complexes $\left[\left(\operatorname{Im}^{\text {Dipp }} \mathrm{N}\right) \mathrm{M}\left(\eta^{5}-\mathrm{C}_{2} \mathrm{~B}_{9} \mathrm{H}_{11}\right)(\mathrm{THF})_{2}\right](\mathbf{9})$. The solid state structures of the complexes 9a and 9b were determined by X-ray diffraction analyses, and the molecular structure of 9a is shown in Figure 7. The coordination spheres around the metal atoms (Sc and Y) can be described as distorted tetrahedra or as three-legged piano-stool geometries, respectively. The metal atoms are bound in $\eta^{5}$-fashion to the pentagonal $\eta^{5}-\mathrm{C}_{2} \mathrm{~B}_{3}$ bonding face of the carborane. 
In addition to the imidazolin-2-iminato and the carboranyl ligand, two THF molecules are bound to the scandium and yttrium atoms. The M-N bond lengths in 9a [1.9466(12) $\AA$ ] and 9b $[2.0829(14) \AA]$ are considerably shorter than in the starting materials $\mathbf{2 a}$ and $\mathbf{2 b}{ }^{[41,42]}$ In fact, complex $9 \mathbf{b}$ features the shortest yttrium-nitrogen bond length reported to date for imidazolin-2-iminato yttrium complexes (Table 1). ${ }^{[42,43]}$

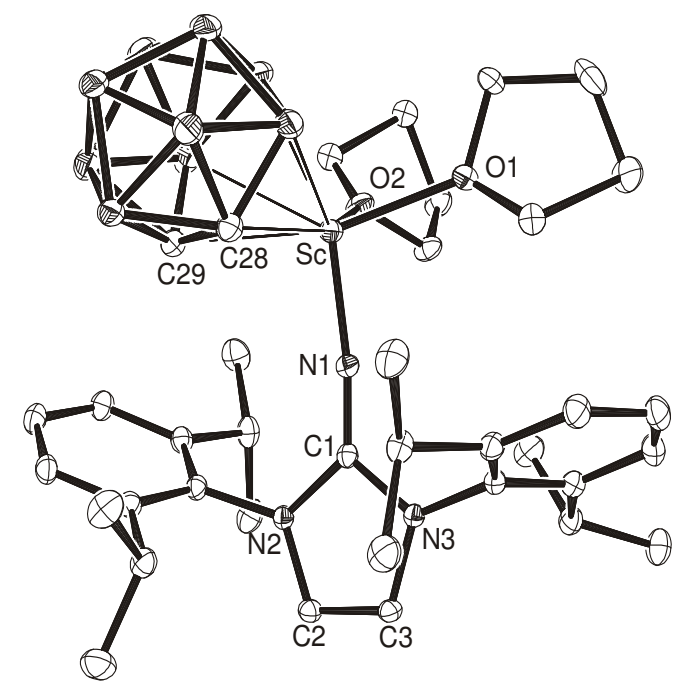

Figure 7. ORTEP diagram of 9a with thermal displacement parameters drawn at $50 \%$ probability.

An acid-base route was followed for the introduction of a carboranyl ligand containng an additional appended $\mathrm{Me}_{2} \mathrm{NCH}_{2} \mathrm{CH}_{2}$ sidearm. ${ }^{[73]}$ Coordination of this functional group is expected to stabilize the resulting carboranyl complexes and to prevent ligand redistribution reactions. The bis(neosilyl) complexes of $\mathbf{4 a}-\mathbf{4 c}$ proved to be suitable starting materials for the reaction with the zwitterionic compound [nido- $\left(\mathrm{Me}_{2} \mathrm{NHCH}_{2} \mathrm{CH}_{2}\right) \mathrm{C}_{2} \mathrm{~B}_{9} \mathrm{H}_{11}$ ], which afforded - after elimination of two equivalents of TMS - the desired products $\left[\left(\operatorname{Im}^{\text {Dipp }} \mathrm{N}\right) \mathrm{M}\left(\eta^{1}: \eta^{5}-\left(\mathrm{Me}_{2} \mathrm{NCH}_{2} \mathrm{CH}_{2}\right) \mathrm{C}_{2} \mathrm{~B}_{9} \mathrm{H}_{10}\right\}(\mathrm{THF})\right](\mathbf{1 0 a}$ - 10c) in moderate yields (Scheme 9). ${ }^{[80]} \mathbf{1 0 a}$ - 10c were characterised by X-ray diffraction analyses, and the molecular structure of 10a is shown in Figure 8. In all cases, the carborane ligand binds in a chelating fashion with the metal atoms being $\eta^{5}$-coordinated by the pentagonal $\mathrm{C}_{2} \mathrm{~B}_{3}$ bonding face and 
additionally $\sigma$-bound to the nitrogen atom of the appended $\mathrm{Me}_{2} \mathrm{~N}$ functional group. The coordination spheres are completed by one $\operatorname{Im}^{\text {Dipp }} \mathrm{N}$ ligand and one THF molecule to afford pseudo-tetrahedral geometries. It is interesting to note that the carboranyl ligand in complexes $\mathbf{1 0}$ is bound in significantly more asymmetric fashion than in complexes $\mathbf{9}$ and shows a slip distortion with a particular elongation of the M-C28 bond. The M-N bond lengths in 10a, 10b and 10c are again very short (Table 1), and 10c features the shortest Lu-N bond [2.068(2) $\mathrm{A}]$ reported to date.

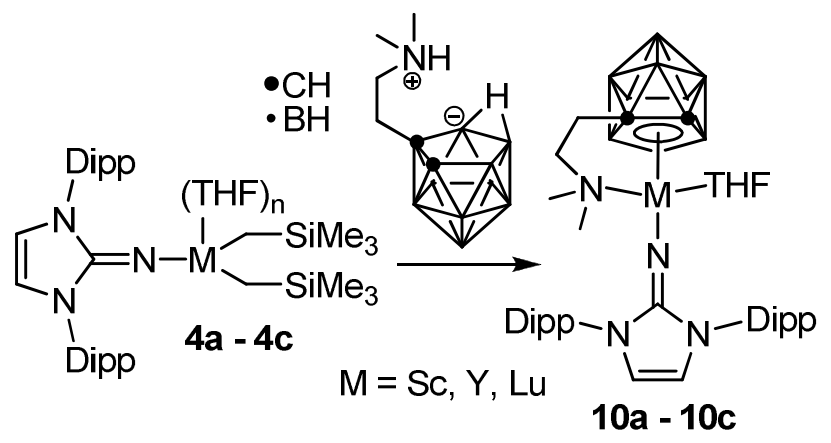

Scheme 9. Preparation of carboranyl complexes 10a - 10c through the acid-base route.

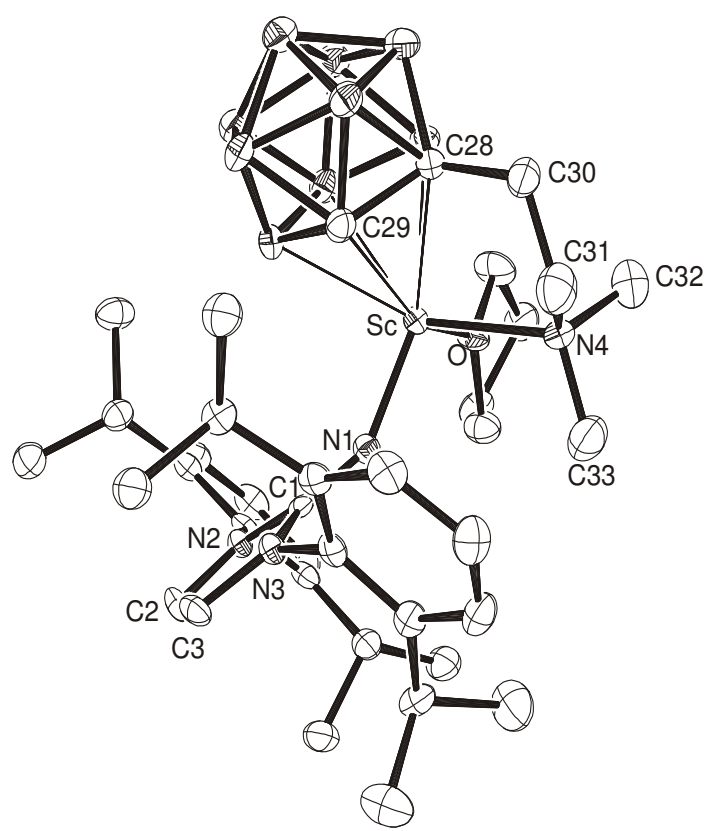

Figure 8. ORTEP diagram of 10a with thermal displacement parameters drawn at $50 \%$ probability. 


\subsection{Cyclooctatetraenyl complexes}

The second most important carbocyclic ligand in organo-f-element chemistry is the $10 \pi$ electron aromatic cyclooctatetraene dianion $\mathrm{C}_{8} \mathrm{H}_{8}{ }^{2-}$, which is well suited to form stable mononuclear complexes with the rare earth elements. ${ }^{[14,15,81]}$ In a similar fashion as described for the carboranyl complexes $\mathbf{9}$, the substitution of the two chloride ligands in complexes $\mathbf{2}$ by $\mathrm{C}_{8} \mathrm{H}_{8}{ }^{2-}$ afforded the cyclooctatetraenyl (COT) complexes of the type $\left[\left(\operatorname{Im}^{\mathrm{Dipp}} \mathrm{N}\right) \mathrm{M}\left(\eta^{8}-\right.\right.$ $\left.\left.\mathrm{C}_{8} \mathrm{H}_{8}\right)(\mathrm{THF})_{2}\right] \mathbf{1 1 b}-\mathbf{1 1 d}$ for $\mathrm{M}=\mathrm{Y}, \mathrm{Lu}, \mathrm{Gd}$, whereas the smaller scandium atom in complex $\left[\left(\operatorname{Im}^{\text {Dipp }} \mathrm{N}\right) \operatorname{Sc}\left(\eta^{8}-\mathrm{C}_{8} \mathrm{H}_{8}\right)(\mathrm{THF})\right](\mathbf{1 1 a})$ allows the coordination of just one additional THF molecule (Scheme 10). ${ }^{[41,42]}$

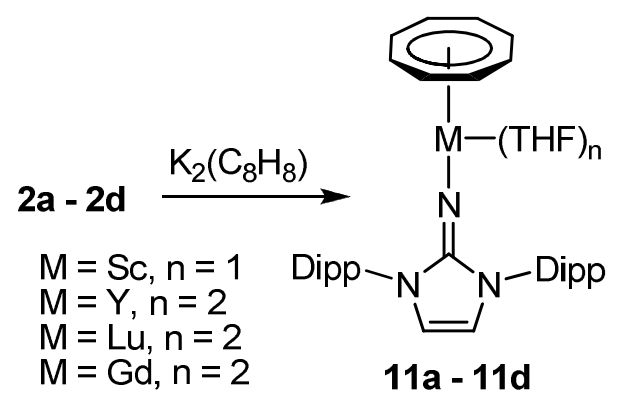

Scheme 10. Preparation of the cyclooctatetraenyl (COT) complexes 11.

The molecular structures of 11a - 11d could be established by X-ray diffraction analyses. The COT ligand in 11a - 11d is essentially $\eta^{8}$-bound, albeit in a slightly distorted fashion. Figure 9 displays the solid state structure of compounds 11a and 11b. The coordination sphere at the scandium atom is completed by one THF ligand to afford a two-legged piano-stool geometry, whereas the coordination spheres at yttrium, lutetium and gadolinium are completed by two additional THF ligands to give three-legged piano-stool geometries. In all cases, the metal-nitrogen bond lengths are marginally elongated in comparison to complexes 2, which is accompanied by a greater deviation the M-N1-C1 angles from linearity (Table 1). This observation might be a result of the strong $\delta$-interaction between the metal atoms and the cyclooctatetraene dianion, which can act as a $10 \pi$-electron donor. ${ }^{[81]}$ 

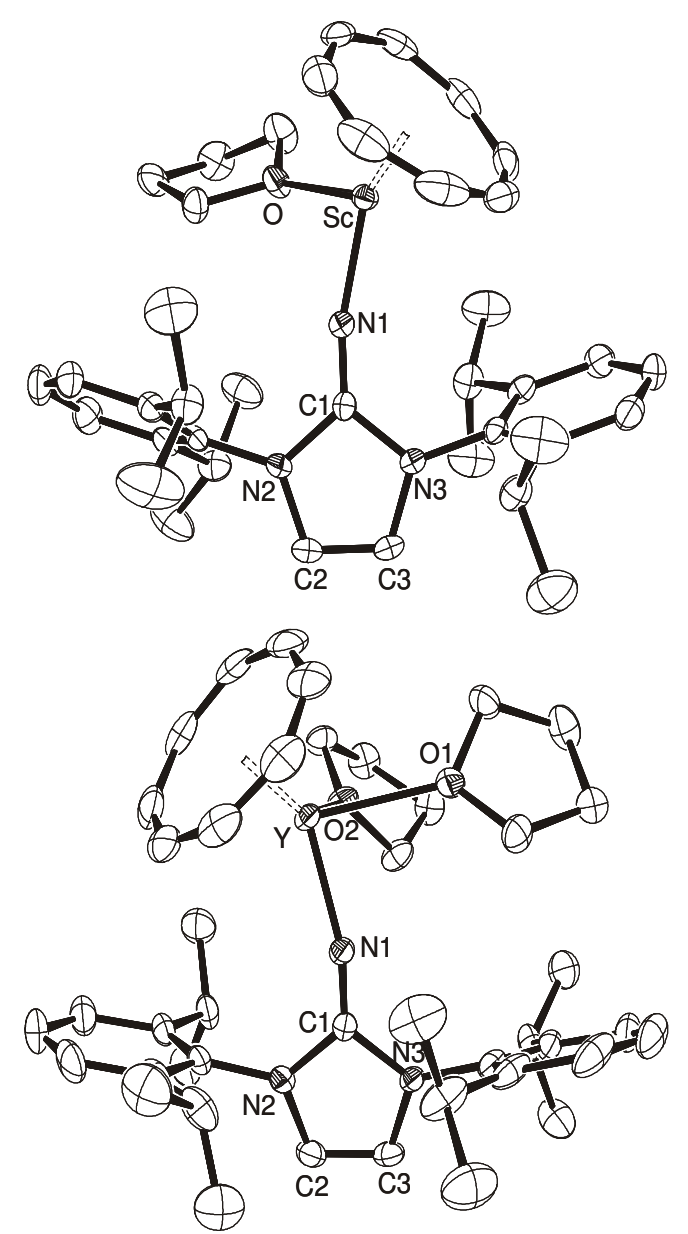

Figure 9. ORTEP diagrams of 11a (top) and 11b (bottom) with thermal displacement parameters drawn at $50 \%$ probability.

It is important to note that imidazolin-2-iminato ligands can be regarded as monoanionic analogues of dinegative imido ligand, $\mathrm{RN}^{2-}$, because of their ability to act as $2 \sigma, 4 \pi$-electron donors (vide supra, Scheme 1), and therefore, the rare earth metal complexes presented in this review article can be regarded as structural models for elusive terminal imido rare earth metal complexes, in which the imido group is generally found to bind in bridging or capping fashion. ${ }^{\left[{ }^{82]}\right.}$ Consequently, the $\left[\left(\mathrm{Im}^{\mathrm{Dipp}} \mathrm{N}\right) \mathrm{Sc}\left(\eta^{8}-\mathrm{C}_{8} \mathrm{H}_{8}\right)\right]$ fragment in 11a can be regarded as isolobal and isoelectronic with the 16-electron titanium imido complexes of the type $\left[(\mathrm{RN}) \mathrm{Ti}\left(\eta^{8}-\mathrm{C}_{8} \mathrm{H}_{8}\right)\right](\mathrm{R}=t \mathrm{Bu}, \mathrm{Dipp}) .{ }^{[83]}$ The reactivity of these unique one-legged pianostool(“pogo-stick") imido complexes towards a variety of organic substrates such as $\mathrm{CO}_{2}$, $\mathrm{CS}_{2}$, isocyanates and isothiocyanates was studied by Mountford and coworkers, and the 
Ti(NR) moiety was shown to undergo a number of cycloaddition-elimination reactions. ${ }^{[84]}$ Accordingly, the reaction of 11a with similar substrates was studied, since the 16-electron $\left[\left(\operatorname{Im}^{\text {Dipp }} \mathrm{N}\right) \operatorname{Sc}\left(\eta^{8}-\mathrm{C}_{8} \mathrm{H}_{8}\right)\right]$ fragment, provided by elimination of the THF ligand, could be expected to exhibit similar reactivity. ${ }^{[42]}$ Exposure of a toluene solution of $\mathbf{1 1 a}$ to $\mathrm{CO}_{2}$ produced a brownish insoluble precipitate that might be tentatively described as a scandium oxo species, considering the formation of oligomeric $\left[\left(\eta^{8}-\mathrm{C}_{8} \mathrm{H}_{8}\right) \mathrm{Ti}=\mathrm{O}\right]$ from $\left[\left(\eta^{8}-\right.\right.$ $\left.\left.\mathrm{C}_{8} \mathrm{H}_{8}\right) \mathrm{Ti}(\mathrm{N} t \mathrm{Bu})\right]$ and $\mathrm{CO}_{2} \cdot{ }^{[84]}$ In contrast, a stable cycloaddition product could be isolated from the reaction of 11a with the isothiocyanate Xy-NCS to afford complex 12 with an unusual thioureato- $N, N$ ' moiety (Scheme 11, Figure 10). This result was in contrast to the observation made for the reaction of $\left[\left(\eta^{8}-\mathrm{C}_{8} \mathrm{H}_{8}\right) \mathrm{Ti}(\mathrm{NDipp})\right]$ with Xy-NCS, which was reported to result in the formation of an N,S-bound cycloaddition product, in agreement with its decomposition to afford the carbodiimide Dipp-N=C=N=Xy. ${ }^{[84]}$

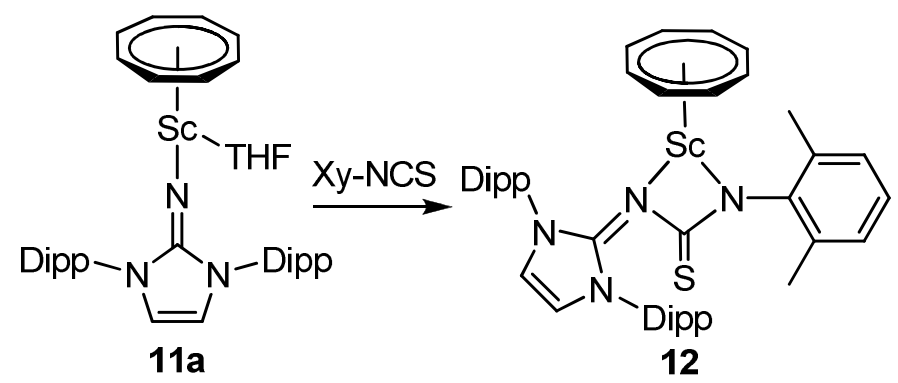

Scheme 11. Synthesis of the [2+2] cycloaddition product 12.

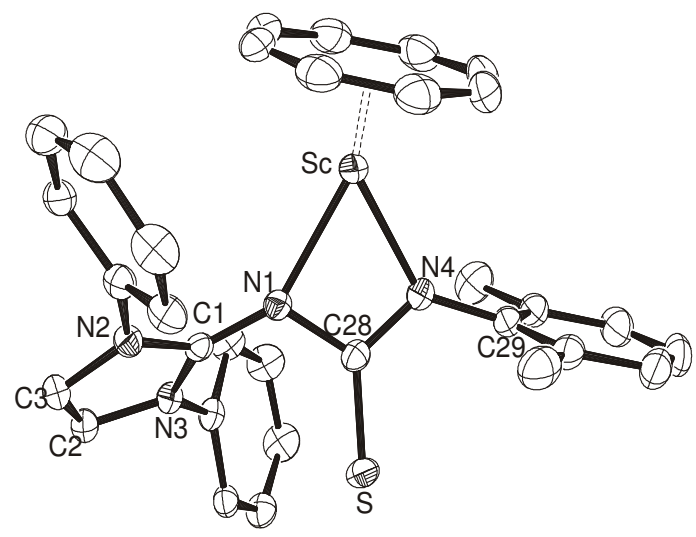

Figure 10. ORTEP diagram of 12 with thermal displacement parameters drawn at $50 \%$ probability. 


\section{Bis(imidazolin-2-iminato) rare earth metal complexes}

\subsection{Monochloro complexes}

As mentioned before, the imidazolin-2-iminato ligands can be regarded as monodentate analogues of cyclopentadienyls, because of their ability to act as $2 \sigma, 4 \pi$-electron donors, $\mathrm{C}_{5} \mathrm{R}_{5}$. Consequently, bis(imidazolin-iminato) complexes of the type $\left[\left(\operatorname{Im}^{\text {Dipp }} \mathrm{N}\right)_{2} \mathrm{MR}(\mathrm{THF})_{\mathrm{n}}\right]$ might be regarded as analogues of metallocene or lanthanocene complexes of the type $\left[(\mathrm{Cp})_{2} \mathrm{MR}(\mathrm{THF})_{\mathrm{n}}\right]$, which have found widespread use in homogeneous catalysis. ${ }^{[13]}$ Following the same strategy as described for the preparation of the dichloro complexes $\mathbf{2 a}-\mathbf{2} \mathbf{c},{ }^{[41,42]}$ the reaction of anhydrous rare earth metal halides $\mathrm{MCl}_{3}(\mathrm{M}=\mathrm{Sc}, \mathrm{Y}, \mathrm{Lu})$ with two equivalents of the imine $\mathrm{Im}^{\mathrm{Dipp}} \mathrm{NH}$ and two equivalents of trimethylsilylmethyl lithium $\left(\mathrm{Me}_{3} \mathrm{SiCH}_{2} \mathrm{Li}\right)$ in THF afforded the imidazolin-2-iminato complexes $\left[\left(\operatorname{Im}^{\text {Dipp }} \mathrm{N}\right)_{2} \mathrm{MCl}(\mathrm{THF})_{2}\right](\mathbf{1 4 a}, \mathrm{M}=\mathrm{Sc}$; $\mathbf{1 4 b}, \mathrm{M}=\mathrm{Y} ; \mathbf{1 4 c}, \mathrm{M}=\mathrm{Lu})$ in very good yields (Scheme 12$).{ }^{[85]}$

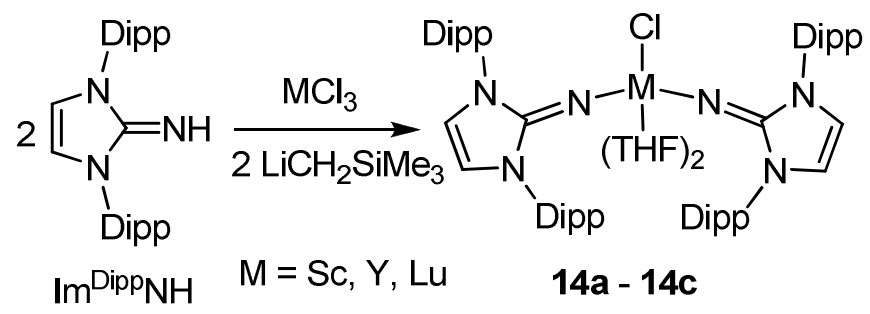

Scheme 12. Synthesis of the bis(imidazolin-2-iminato) complexes 14.

X-ray diffraction analysis reveals in all cases - Figure 11 shows the yttrium complex 14b - a five-coordinated metal atom, which resides in a trigonal-bipyramidal coordination sphere, with the THF ligands adopting the axial positions. The orientation of the three anionic equatorial ligands, the two iminato ligands and the chlorine atom, is nearly perfectly trigonalplanar with the sum of the N-M-N and N-M-Cl angles being almost $360^{\circ}$. It should be noted that the related lanthanocene complexes tend to form dinuclear complexes or cluster of higher nuclearity, in which the metal atoms are bridged by chloride atoms. ${ }^{[7]}$ The imidazolin2-iminato ligands in $\mathbf{1 4 a} \mathbf{- 1 4 c}$ coordinate in almost perfectly linear fashions, indicating that 
two $\operatorname{Im}^{\text {Dipp }} \mathrm{N}$ ligands are conveniently accommodated at the metal atoms. However, the introduction of the second ligands goes along with an increase of the metal-nitrogen bond lengths in comparison with the structures of the dichloro complexes $\mathbf{2}$ (Table 2).

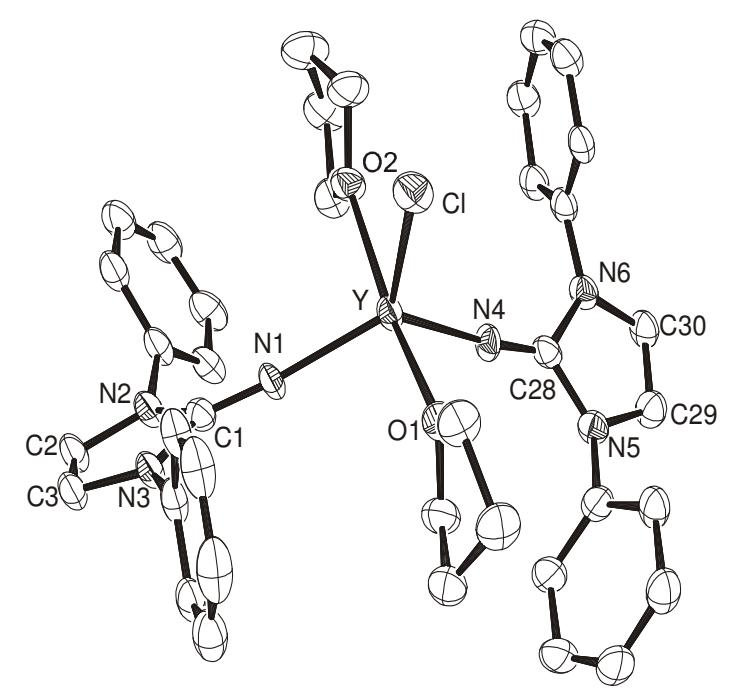

Figure 11. ORTEP diagram of $\mathbf{1 4 b}$ with thermal displacement parameters drawn at $50 \%$ probability; the isopropyl groups have been omitted for clarity.

Interestingly, the related reaction between $\mathrm{Im}^{\text {Dipp }} \mathrm{NH}, \mathrm{YbI}_{2}$ and $\mathrm{LiCH}_{2} \mathrm{SiMe}_{3}$ did not lead to the formation of an ytterbium(II) complex containing the $\left[\left(\operatorname{Im}^{\text {Dipp }} \mathrm{N}\right)_{2} \mathrm{Yb}\right]$ complex fragment, but instead the $\mathrm{Yb}(\mathrm{III})$ complex $\left[\left(\mathrm{Im}^{\mathrm{Dipp}} \mathrm{N}\right)_{2} \mathrm{YbI}(\mathrm{THF})_{2}\right](\mathbf{1 5})$ was isolated as a yellow crystalline material. The reaction is accompanied by the formation of a grey precipitate, presumably $\mathrm{Yb}$ metal, indicating that $\mathbf{1 5}$ has formed by disproportionation (Scheme 13). ${ }^{[9]}$ We assume that the electron richness of the imidazolin-2-iminato ligand prevents the isolation of a stable divalent lanthanide complex. 15 was also characterized by Xray diffraction analysis, revealing a molecular structure, which is very similar to the fivecoordinate structures established for the chloro complexes 14 (Figure 11). As expected, the Yb-N bond distances are short [2.109(3), 2.104(3) ̊]. 


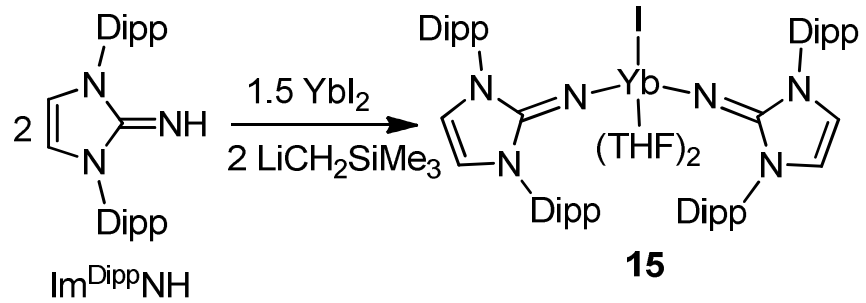

Scheme 13. Synthesis of the bis(imidazolin-2-iminato) ytterbium(III) complex 15.

\subsection{Mono(neosilyl) complexes}

Catalytically active lanthanide complexes for olefin polymerisation, hydroamination or hydrosilylation reactions should contain at least one kinetically labile $\sigma$-bonded ligand. Accordingly, substitution of the chlorine atoms from the complexes $\mathbf{1 4}$ by an alkyl group could afford useful homogeneous catalysts, e. g. for hydroamination, hydrosilylation or polymerisation reactions. Therefore, the reaction of $\mathbf{1 4 a}-\mathbf{1 4} \mathbf{c}$ with one equivalent of $\mathrm{LiCH}_{2} \mathrm{SiMe}_{3}$ was carried out in THF (Scheme 14), leading to the formation of the neosilyl complexes $\left[\left(\mathrm{Im}^{\mathrm{Dipp}} \mathrm{N}\right)_{2} \mathrm{M}\left(\mathrm{CH}_{2} \mathrm{SiMe}_{3}\right)(\mathrm{THF})_{\mathrm{n}}\right](\mathbf{1 6 a}$ - 16c). NMR spectroscopy indicates that the scandium complex $\mathbf{1 6 a}$ contains only one additional THF ligand bound to the metal atom $(n=1)$, whereas the $Y$ and Lu congeners contain two THF molecules.
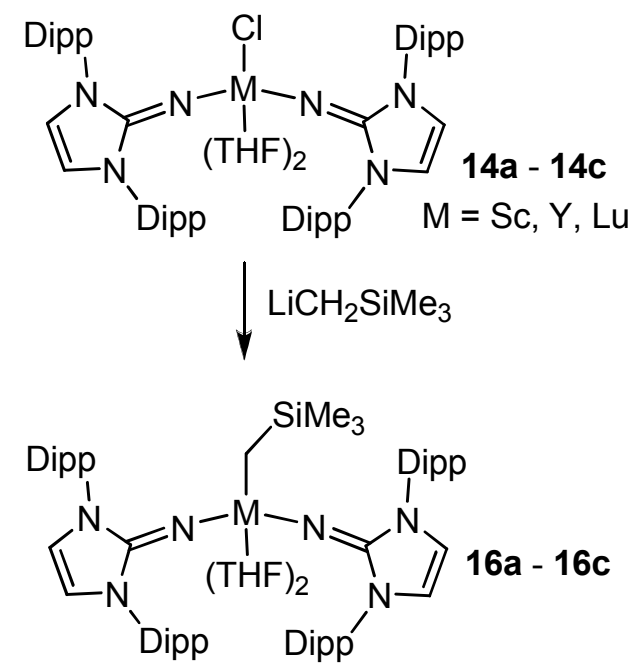

Scheme 14. Synthesis of the neosilyl complexes 16. 
For $\mathbf{1 6 b}$ and 16c, the complex composition was additionally proved by X-ray diffraction analysis. The two complexes $(\mathbf{1 6 b}$ and $\mathbf{1 6 c})$ are isostructural, and the coordination geometry at the metal atoms is similar to that found for the starting materials $\mathbf{1 4}$, although the introduction of the neosilyl ligand produces a significantly stronger distortion from an ideal trigonalbipyramidal orientation. The yttrium compound $\mathbf{1 6 b}$ was additionally characterized by ${ }^{89} \mathrm{Y}$ NMR spectroscopy, giving rise to a singlet at $-800.1 \mathrm{ppm}$. Comparison with the resonance observed for the corresponding bis(neosilyl) complex $\mathbf{4 b}$ at $+813.8 \mathrm{ppm}$ indicates a high-field shift of more than 1600 ppm. ${ }^{[43]}$ As reported by Schaverien and Hanusa, ${ }^{[60]}$ the ${ }^{89}$ Y NMR resonance is expected to shift progressively to higher field as $\sigma$-donating alkyl groups, for instance from $\left[\mathrm{Y}\left(\mathrm{CH}_{2} \mathrm{SiMe}_{3}\right)_{3}(\mathrm{THF})_{2}\right],{ }^{[59]}$ are sequentially substituted by groups of increased electronegativity and $\pi$-donating ability. ${ }^{[58 c, 86]}$ Consequently, the observed dramatic high-field shift upon introduction of a second imidazolin-2-iminato ligand produces once again proof for the strong electron-donating ability of these ligand system.

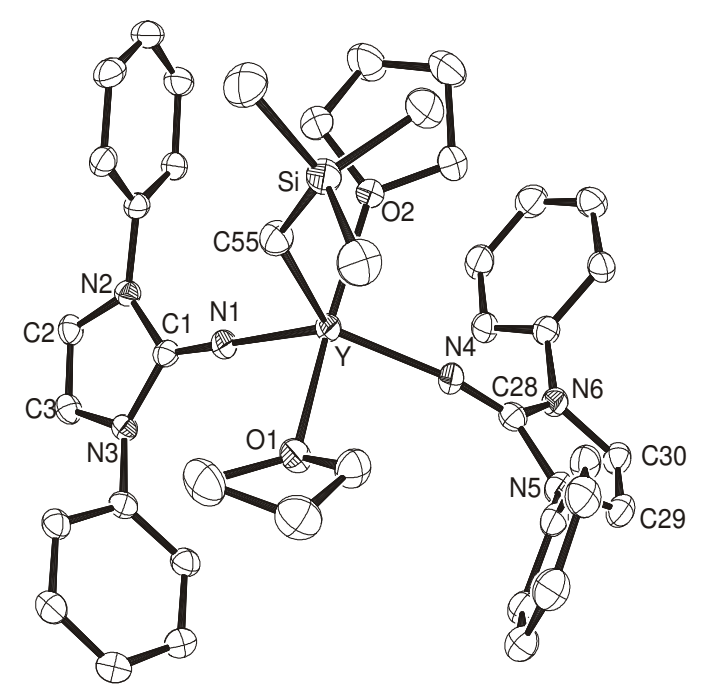

Figure 12. ORTEP diagram of $\mathbf{1 6} \mathbf{b}$ with thermal displacement parameters drawn at $50 \%$ probability; the isopropyl groups have been omitted for clarity. 


\section{Homoleptic imidazolin-2-iminato rare earth metal complexes}

Since the mono- and bis(imidazolin-2-iminato) rare earth metal complexes described above might be regarded as analogues of mono- and bis(cyclopentadienyl) complexes, tris(imidazolin-2-iminato) complexes might be regarded as isolobal to tris(cyclopentadienyl) complexes $\left[(\mathrm{Cp})_{3} \mathrm{M}\right]^{[7]}$ and to homoleptic tris(phosphoraneiminato) complexes $\left[\mathrm{M}\left(\mathrm{NPR}_{3}\right)_{3}\right] .{ }^{[21]}$ For the latter, however, only dinuclear species such as $\left[\mathrm{M}\left(\mathrm{NPPh}_{3}\right)_{3}\right]_{2} \quad(\mathrm{M}=\mathrm{Y}$, La) were reported, which can be used as initiators for the ring-opening polymerisation of lactones. ${ }^{[87]}$ The acid-base reaction between the rare earth metal tris(neosilyl) complexes $\left.\mathrm{M}\left(\mathrm{CH}_{2} \mathrm{SiMe}_{3}\right)_{3}(\mathrm{THF})_{2}\right](\mathrm{M}=\mathrm{Sc}, \mathrm{Y}, \mathrm{Lu})$ and three equivalents of 1,3-diisopropyl-4,5dimethylimidazolin-2-imine $\left(\mathrm{Im}^{i \mathrm{Pr}} \mathrm{NH}\right)$ in hexane cleanly afforded the tris(imidazolin-2iminato) complexes 17 with release of tetramethylsilane (Scheme 15). ${ }^{[88]}$ The molecular structures of 17a - 17c were established by X-ray diffraction analyses, revealing the presence of dimeric complexes of the type $\left[\mathrm{M}_{2}\left(\operatorname{Im}^{i \operatorname{Pr}} \mathrm{N}\right)_{6}(\mathrm{THF})_{\mathrm{n}}\right]$ in the solid state. The scandium complex 17a $(n=0)$ forms a centrosymmetric dimer of $\left[\mathrm{Sc}_{2}\left(\operatorname{Im}^{i P r} \mathrm{~N}\right)_{6}\right]$ with the two scandium atoms connected by two bridging $\mu_{2}-\mathrm{Im}^{i \mathrm{Pr}} \mathrm{N}$ groups to generate a $\mathrm{Sc}_{2} \mathrm{~N}_{2}$ square. In contrast, the dimeric complex units in $\left[\mathrm{Y}_{2}\left(\operatorname{Im}^{i \operatorname{Pr}} \mathrm{N}\right)_{6}(\mathrm{THF})\right](\mathbf{1 7 b})$ and $\left[\mathrm{Lu}_{2}\left(\operatorname{Im}^{i \operatorname{Pr}} \mathrm{N}\right)_{6}(\mathrm{THF})\right]$ (17c) contain two metal atoms each, which display different coordination geometries, since one metal atom coordinates an additional THF molecule to acquire a coordination number of five, whereas the other atom remains in a distorted tetrahedral environment (see Figure 13 for the molecular structure of $\mathbf{1 7 b}$ ). In all complexes, the terminal metal-nitrogen distances are shorter than those to the bridging nitrogen atoms; however, they are longer than observed for mono- and bis(imidazolin-2-iminato) complexes (Table 3). 


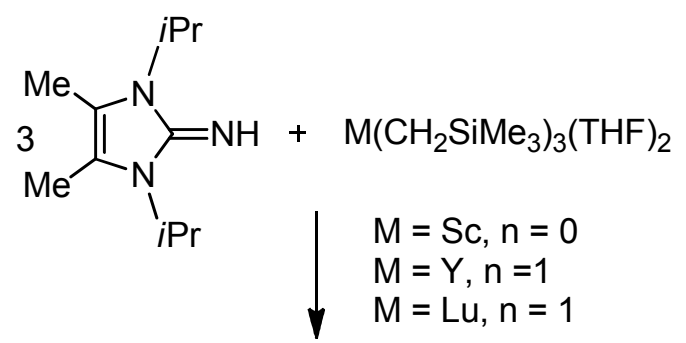

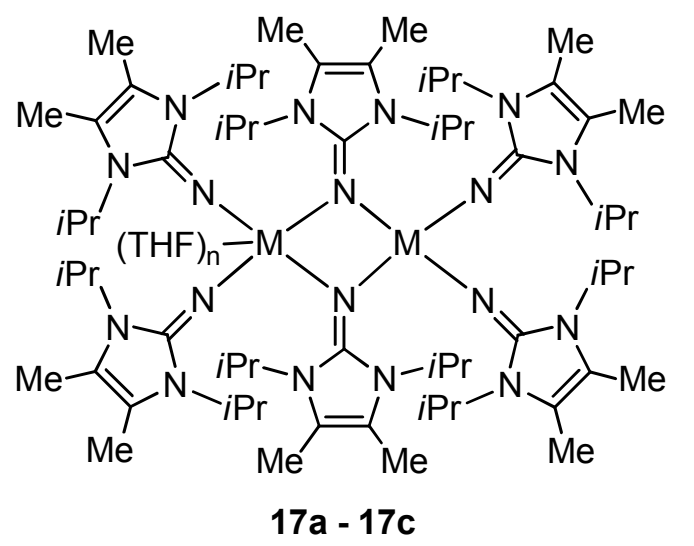

Scheme 15. Synthesis of the complexes $\left[\left(\operatorname{Im}^{\mathrm{R}} \mathrm{N}\right)_{6} \mathrm{M}(\mathrm{THF})_{\mathrm{n}}\right](\mathbf{1 7})$.

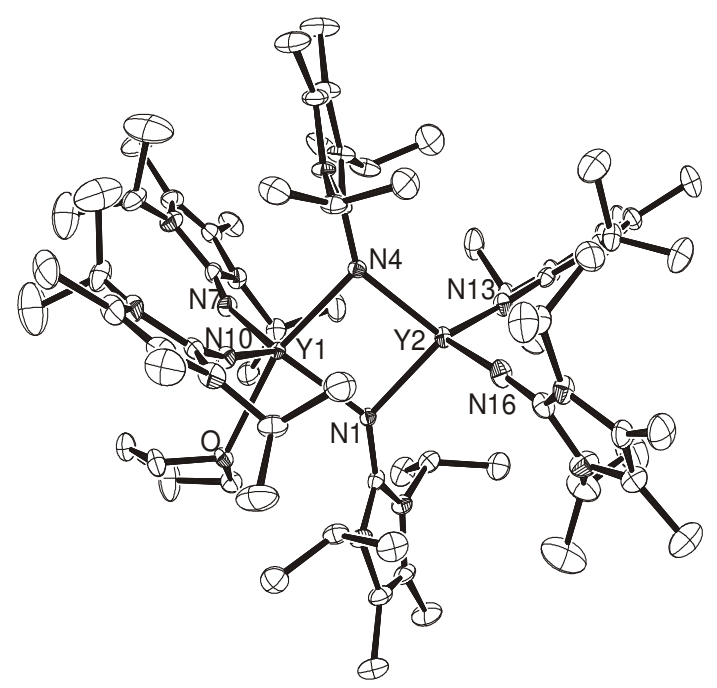

Figure 13. ORTEP diagram of $\mathbf{1 7 b}$ with thermal displacement parameters drawn at $50 \%$ probability.

To investigate whether the introduction of a more sterically demanding imidazolin-2iminato ligand would affect the nuclearity of the resulting rare earth metal complexes, a

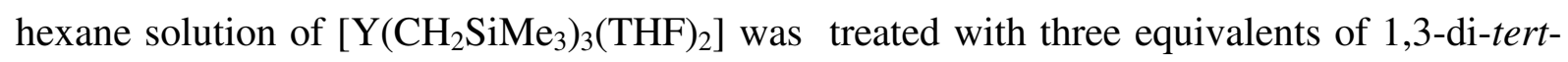
butylimidazolin-2-imine $\left(\operatorname{Im}^{t \mathrm{Bu}} \mathrm{NH}\right)$ to afford $\left[\mathrm{Y}\left(\operatorname{Im}^{t \mathrm{Bu}} \mathrm{N}\right)_{3}(\mathrm{THF})_{2}\right]$ (18) as a colourless, crystalline solid in almost quantitative yield. The molecular structure of $\mathbf{1 8}$ is shown in Figure 
14, revealing that a monomeric complex has formed, in which the yttrium atom attains a coordination number of five and exhibits a coordination sphere that adopts an intermediate position between the perfectly trigonal-bipyramidal and square-pyramidal geometries. ${ }^{[88]}$ For comparison, the analogous monuclear cyclopentadienyl complex $\left[(\mathrm{Cp})_{3} \mathrm{Y}\right]$ ccoordinates only one solvent molecule upon crystallization from THF solution. ${ }^{[89]}$

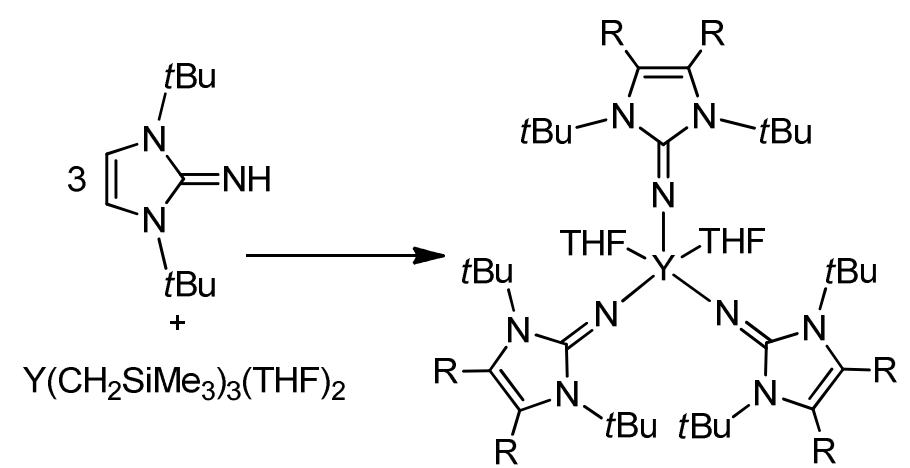

18

Scheme 16. Synthesis of the homoleptic complex $\left[\left(\operatorname{Im}^{\mathrm{tBu}} \mathrm{N}\right)_{3} \mathrm{Y}\right](\mathbf{1 8})$.

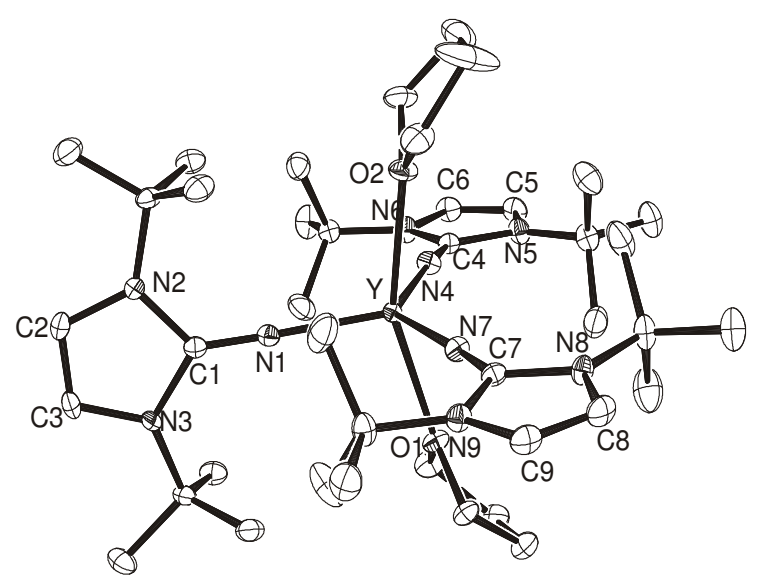

Figure 14. ORTEP diagram of $\mathbf{1 8}$ with thermal displacement parameters drawn at $50 \%$ probability. 


\section{Constrained-Geometry ligands}

Imidazolin-2-imines $\left(\operatorname{Im}^{\mathrm{R}} \mathrm{N}\right)$ are not only valuable ligand precursors in their own right, but they also serve as useful building blocks for the design and preparation of novel multidentate poly(imidazolin-2-imine) ligands. ${ }^{\left[{ }^{[9-92]}\right.}$ The tethering of an imidazolin-2-imine unit to a cyclopentadienyl ring through a $\mathrm{Me}_{2} \mathrm{Si}$ bridge leads to cyclopentadienyl-imidazolin-2-imine ligands, which can be expected to form "constrained-geometry" ansa-cyclopentadienyl-amido complexes, despite the overall neutral charge of the imine moiety. The imidazolin-2-iminotetramethylcyclopentadiene ligand $\mathbf{1 9}-\mathrm{H}$ can be obtained as a yellow oil from the reaction of 5-(chlorodimethylsilyl)-1,2,3,4-tetramethyl-1,3-cyclopentadiene with two equivalents of 1,3diisopropyl-4,5-dimethyl-imidazolin-2-imine $\left(\operatorname{Im}^{i \operatorname{Pr}} \mathrm{NH}\right)$. One equivalent of the imine serves as a hydrochloric acid scavenger and precipitates from the reaction mixture as the corresponding 2-aminoimidazolium chloride, $\operatorname{Im}^{i P r} \mathrm{NH} \cdot H C l .{ }^{[93]}$

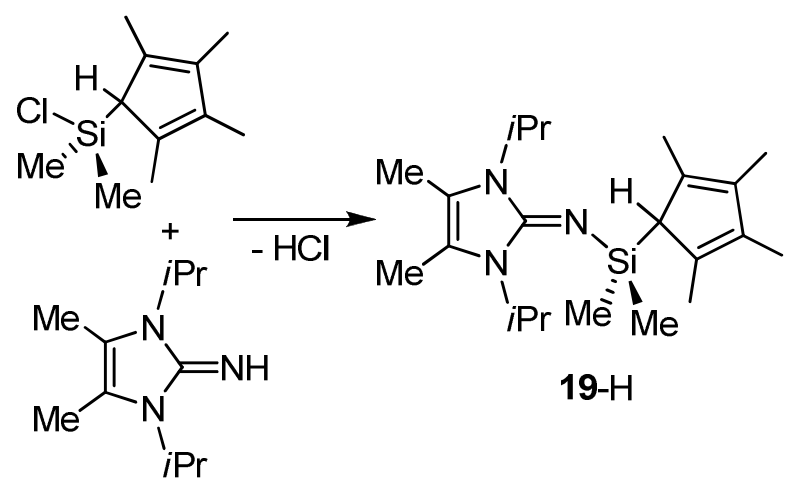

Scheme 17. Synthesis of the imine-functionalized cyclopentadiene 19-H.

Treatment of 19-H with rare earth metal trialkyl complexes [ $\left.\mathrm{Ln}\left(\mathrm{CH}_{2} \mathrm{SiMe}_{3}\right)_{3}(\mathrm{THF})_{2}\right](\mathrm{Ln}$ $=\mathrm{Sc}, \mathrm{Y}, \mathrm{Lu})$ in hexane at ambient temperature generated the cyclopentadienide ligand $\mathbf{1 9}$, which coordinates in a chelating fashion to afford the solvent-free complexes $\left[\left(\eta^{5}: \eta^{1}-\mathrm{C}_{5} \mathrm{Me}_{4^{-}}\right.\right.$ $\left.\left.\mathrm{SiMe}_{2}-\mathrm{NIm}^{i \mathrm{Pr}}\right) \mathrm{M}\left(\mathrm{CH}_{2} \mathrm{SiMe}_{3}\right)_{2}\right](\mathbf{2 0})$ in good yields (Scheme 18). ${ }^{[94]} \mathbf{2 0 a}$ - 20c were characterized by X-ray diffraction analyses; all complexes exhibit a three-legged piano-stool geometry with a distorted pseudo-tetrahedral environment around the metal atoms. As a 
representative, the molecular structure of the lutetium complex $20 \mathrm{c}$ is shown in Figure 15.

Coordination of the tethered imine sidearm leads to a pronounced charge separation as indicated by long $\mathrm{C} 1-\mathrm{N} 1$ bonds and by an orthogonal orientation of the imidazole plane with respect to the plane containing $\mathrm{N} 1$, the metal atom and the centroid of the $\mathrm{Cp}$ ring.

Consequently, these complexes are structurally closely related to well-established and commercialized "constrained-geometry" ansa-cyclopentadienyl-amido complexes containing tetravalent group 4 metals, ${ }^{[95]}$ which also require two monoanionic ligands to attain an overall neutral charge. In contrast, related "true" $\mathrm{Cp}$-amido rare earth metal complexes contain only one only one additional anionic ligand as exemplified by the related neosilyl complexes $\left[\left(\eta^{5}: \eta^{1}-\mathrm{C}_{5} \mathrm{Me}_{4}-\mathrm{SiMe}_{2}-\mathrm{N}-\mathrm{C}_{6} \mathrm{H}_{5}\right) \mathrm{Ln}\left(\mathrm{CH}_{2} \mathrm{SiMe}_{3}\right)(\mathrm{THF})_{2}\right]^{[96]}\left[\left(\eta^{5}: \eta^{1}-\mathrm{C}_{5} \mathrm{Me}_{4}-\mathrm{SiMe}_{2}-\right.\right.$ $\left.\mathrm{N} t \mathrm{Bu}) \mathrm{Y}\left(\mathrm{CH}_{2} \mathrm{SiMe}_{3}\right)(\mathrm{THF})\right]^{[97]}$ and $\left[\left(\eta^{5}: \eta^{1}-\mathrm{C}_{5} \mathrm{Me}_{4}-\mathrm{SiMe}_{2}-\mathrm{NXy}\right) \mathrm{Lu}\left(\mathrm{CH}_{2} \mathrm{SiMe}_{3}\right)(\mathrm{THF})\right](\mathrm{Xy}=$ 2,6-dimethylphenyl). ${ }^{[98]}$<smiles>CC1=C(C)C(C(C)(C)N=c2n(C(C)C)c(C)c(C)n2C(C)C)C(C)=C1C</smiles>

19-H

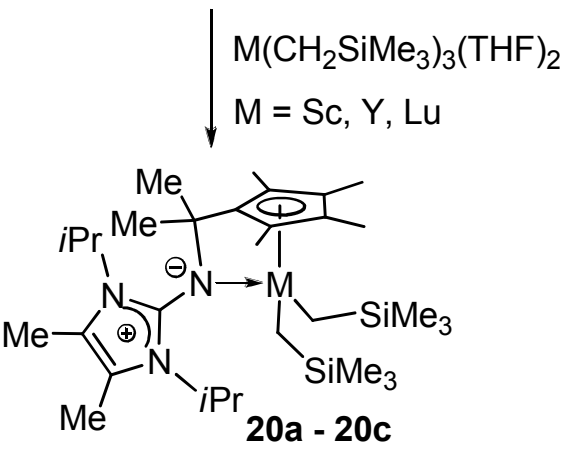

Scheme 18. Synthesis of Cp-imidazolin-2-imine complexes 20. 


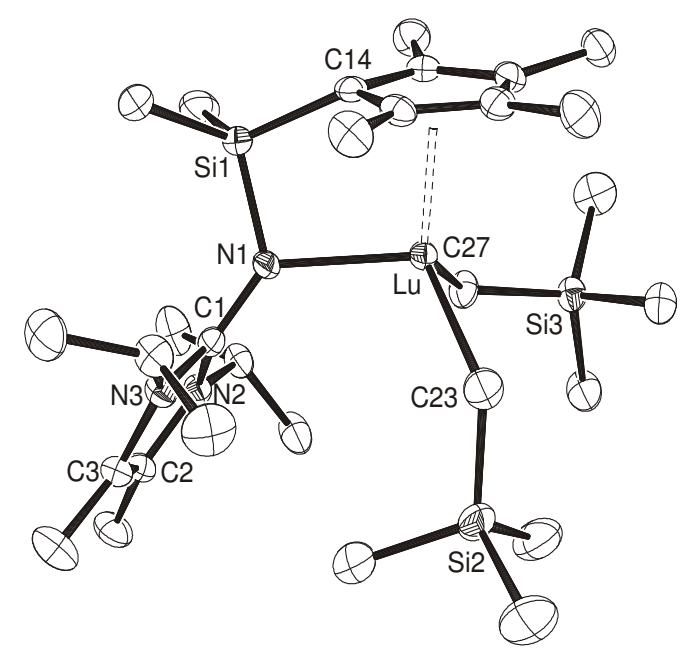

Figure 15. ORTEP diagram of 20c with thermal displacement parameters drawn at $50 \%$ probability.

\section{Rare earth metal complexes containing bis(imidazolin-2- \\ iminato)pyridine pincer ligands}

Bridging two imidazolin-2-imine moieties by a 2,6-dimethylpyridine unit affords the tridentate pincer ligand bis(imidazolin-2-imino)pyridine $\left(\mathrm{TL}^{\mathrm{tBu}}\right)$, which forms stable chelate complexes with numerous 3d-transition metals. ${ }^{[92 a, 99]}$ Since $\mathrm{TL}^{t \mathrm{Bu}}$ can be expected to bind metals in an ylidic amido-type fashion (vide supra), we envisaged that this ligand should also be well suited for the complexation of hard rare earth metal ions. Thus, the reaction with the anhydrous trichlorides $\mathrm{MCl}_{3}(\mathrm{M}=\mathrm{Y}, \mathrm{Er}, \mathrm{Lu})$ in THF afforded the mononuclear complexes $\left[\left(\mathrm{TL}^{\mathrm{tBu}}\right) \mathrm{MCl}_{3}\right](\mathrm{M}=\mathrm{Y}, \mathbf{2 1 a} ; \mathrm{M}=\mathrm{Er}, \mathbf{2 1 b} ; \mathrm{M}=\mathrm{Lu}, \mathbf{2 1 c})$ in excellent yields (Scheme 19). ${ }^{[100]}$ The solid-state structures of compounds 21a and 21c were established by X-ray diffraction analysis, revealing that the coordination polyhedra in both cases are formed by chelation through the two imine and the pyridine nitrogen atoms of the $\mathrm{TL}^{t \mathrm{Bu}}$ ligand and additional coordination of three chloride atoms (see Figure 16 for the molecular structure of 21a). In both complexes, however, the $\mathrm{TL}^{\mathrm{t} \mathrm{Bu}}$ ligand is asymmetrically attached to the metal atoms, and additional short $\mathrm{M} \cdots \mathrm{H}$ contacts are observed between the metal ions and a methyl group from 
one of the tert-butyl groups, which can be regarded as a remote,${ }^{[101]}$ or secondary ${ }^{[102]} \mathrm{C}-$ $\mathrm{H} \cdots \mathrm{M}$ interactions. A DFT (density functional theory) calculation on 21a was able to reproduce this interaction, which was additionally characterized by means of an $\mathrm{H}^{\cdots} \mathrm{Y}$ compliance constant and by employing the AIM (atoms in molecules) theory. ${ }^{[100]}$

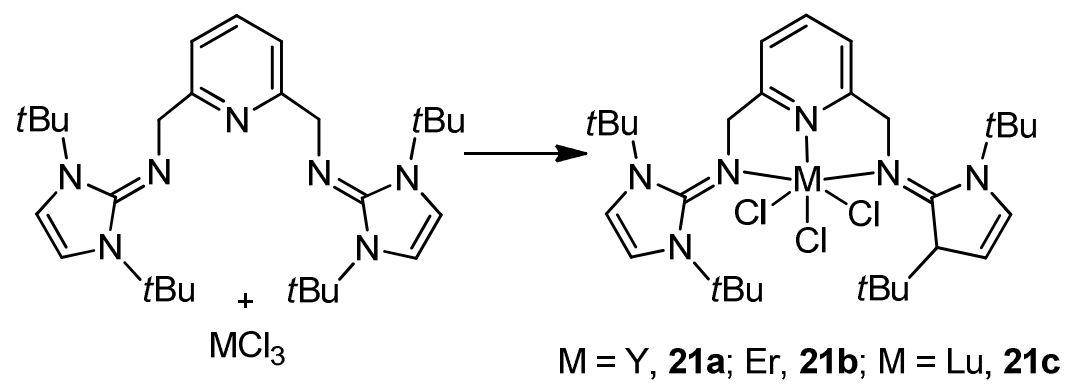

Scheme 19. Synthesis of the complexes $\left[\left(\mathrm{TL}^{t \mathrm{Bu}}\right) \mathrm{MCl}_{3}\right](\mathbf{2 1})$.

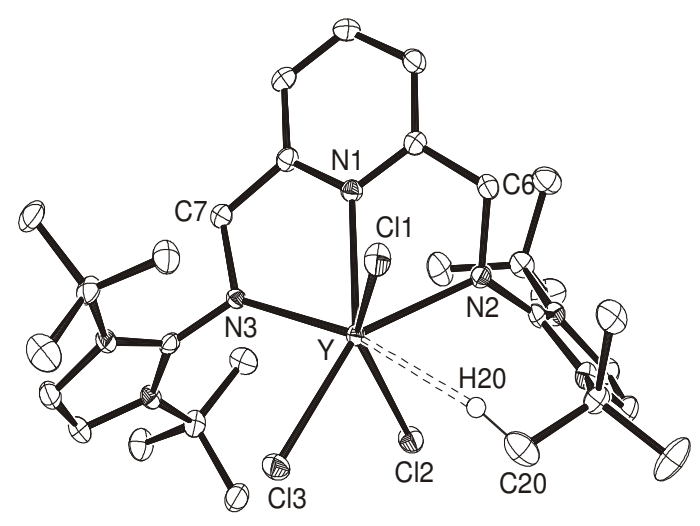

Figure 16. ORTEP diagram of 21a with thermal displacement parameters drawn at $50 \%$ probability.

\section{Catalytic applications}

The number of applications of rare earth metal complexes containing noncyclopentadienyl ligands has become comparable to the plethora of lanthanocene-catalysed homogeneous reactions. ${ }^{[13,28 b, 103-105]}$ This clearly results from the fact that a great number of novel ancillary ligands for the complexation of rare earth metals have been reported in recent 
years (see Figure 1). ${ }^{[21-29]}$ The introduction of the imidazolin-2-iminato ligands to this growing family of ancillary ligands, as versatile alternatives to cyclopentadienyl ligands, led to the formation of viable system for the preparation of catalytically active transition as well as rare earth metal complexes. ${ }^{[33-43]}$ The combination of highly basic nitrogen ligands with Lewisacidic rare earth metal ions should lead to the formation of active catalysts for ring-opening polymerisations. Accordingly, when the ring-opening polymerisation reaction of $\varepsilon^{-}$ caprolactone with the half-sandwich cyclooctatetraene complex 12b was investigated, high catalytic activity was observed, and polylactones are quantitatively formed in less than 5 min. ${ }^{[106]}$ In addition, studies of the intramolecular hydroamination/cyclisation reactions using catalytic amounts of the bis(neosilyl) complexes $\mathbf{4 b}$ and $\mathbf{4 c}$ and the "constrained-geometry" complexes 20a - 20c (Scheme 20, reaction a), were also performed. ${ }^{[43,94]}$ The main focus of the investigation was to evaluate their catalytic activity and to compare them with lanthanocene catalysts ${ }^{[13,105,107]}$ and other non-Cp rare earth metal complexes. ${ }^{[108-111]}$

(a)

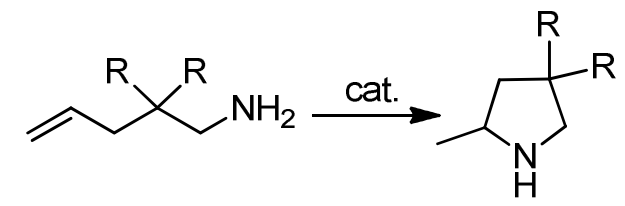

(b)

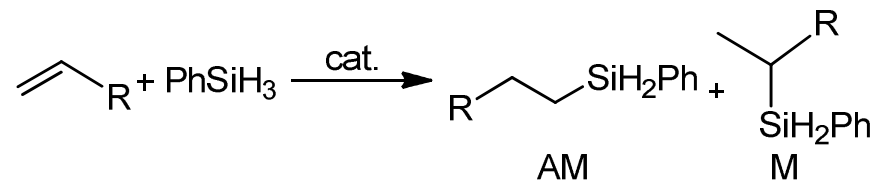

Scheme 20. (a) hydroamination/cyclisation reaction of terminal aminoalkene (b) hydrosilylation reaction of alkenes

The anaerobic hydroamination/cyclisation of aminoalkenes and aminoalkynes catalyzed by complexes $\mathbf{4 b}$ and $\mathbf{4 c}(5 \mathrm{~mol} \%)$ proceeds to completion and is conveniently monitored by ${ }^{1} \mathrm{H}$ NMR spectroscopy. ${ }^{[43]}$ The transformation is effective in the formation of five-membered heterocycles from primary amines at room temperature or higher temperature, respectively. The substrates, bearing bulky geminal substituents in the $\beta$-position to the amino group 
(Thorpe-Ingold effect), ${ }^{[112]}$ could be cyclised within a few minutes in contrast to those bearing less bulky substituents, where the reaction time is increasing and higher reaction temperatures are required. A comparison of the activity of complexes $\mathbf{4 b}$ and $\mathbf{4 c}$ with non-cyclopentadienyl complexes, for example $\left[\mathrm{La}\left\{\mathrm{N}\left(\mathrm{SiHMe}_{2}\right)_{2}\right\}_{2}\left\{\mathrm{CH}\left(\mathrm{PPh}_{2} \mathrm{NSiMe}_{3}\right)\right\}\right],{ }^{[108 \mathrm{e}]}$ shows a significantly higher activity for the former complexes. In comparison with the corresponding metallocene catalysts, for example $\left[\left(\mathrm{Cp}^{*}\right)_{2} \operatorname{Ln}\left\{\mathrm{CH}\left(\mathrm{SiMe}_{3}\right)_{2}\right\}\right]^{[113]}(\mathrm{Ln}=\mathrm{La}, \mathrm{Sm}, \mathrm{Nd})$, the rates for the hydroamination/cyclisation reaction using as catalysts $\mathbf{4 b}$ and $\mathbf{4 c}$ are rather slow. ${ }^{[43]}$

In addition, the catalytic activity of the "constrained-geometry" compounds $20 \mathbf{a}-\mathbf{2 0 c}$ was also evaluated in hydroamination/cyclisation reactions. Yet again, all substrates were converted into cyclic products under mild conditions using low catalyst loadings of 2 to 6 mol\%. However, in comparison with the bis(neosilyl) complexes $4 \mathbf{b}$ and $\mathbf{4 c}$, compounds $\mathbf{2 0 a}$ 20c show lower catalytic activities. ${ }^{[43,94]}$

Besides the intramolecular hydroamination reaction, the bis(neosilyl) $\mathbf{4 b}$ and $\mathbf{4 c}$ were also screened for hydrosilylation reactions and proved to be highly efficient pre-catalysts for the intermolecular hydrosilylation of 1-hexene and 1-octene using a small excess (4\%) of phenylsilane $\left(\mathrm{PhSiH}_{3}\right)$ and $2 \mathrm{~mol} \%$ catalyst loadings (Scheme 20, reaction b). In all cases, the reaction went essentially to completion in less than five minutes at ambient temperature as judged by ${ }^{1} \mathrm{H}$ NMR spectroscopy. Full selectivity for the anti-Markovnikov (AM) products was achieved, and no side reactions were observed. With regard to reaction temperature, catalyst loadings and yields, the activities of compounds $\mathbf{4 b}$ and $\mathbf{4 c}$ are higher than those reported for metallocene complexes, e. g. for the hydrosilylation of 1-hexene in the presence of $\left[\mathrm{Me}_{2} \mathrm{Si}\left(\mathrm{C}_{5} \mathrm{Me}_{5}\right)_{2} \mathrm{SmCH}\left(\mathrm{SiMe}_{3}\right)_{2}\right]$ at room temperature. ${ }^{[114]}$ Moreover, the activities of $\mathbf{4 b}$ and $\mathbf{4 c}$, fall in the range that was recently observed for closely related organoyttrium catalysts of the type $\left[\left\{\mathrm{PhC}(\mathrm{NAr})_{2}\right\} \mathrm{Y}\left(\mathrm{CH}_{2} \mathrm{SiMe}_{3}\right)_{2}(\mathrm{THF})\right]$ and $\left[\left\{\mathrm{Me}_{2} \mathrm{NC}(\mathrm{NAr})_{2}\right\} \mathrm{Y}\left(\mathrm{CH}_{2} \mathrm{SiMe}_{3}\right)_{2}(\mathrm{THF})\right]$ with sterically demanding amidinate and guanidinate ligands, which were shown to be excellent catalysts for the hydrosilylation of various terminal alkenes with phenylsilane and 
which have displayed higher catalytic activity than any other rare earth or early transition metal catalysts. ${ }^{[115]}$

\section{Conclusion}

This overview gives ample evidence for the suitability of imidazolin-2-iminato ligands to form particularly short and strong metal-nitrogen bonds. Experimental and theoretical studies reveal an analogy between imidazolin-2-iminato and conventional imido complexes, and accordingly, the complexes presented in this paper can be regarded as accurate models for elusive mononuclear imido rare earth metal complexes. Despite the presence of highly polarised metal-nitrogen bonds, imidazolin-2-iminato ligands proved to be suitable ancillary ligands for the preparation and generation of efficient catalysts for ring-opening polymerisation, hydroamination and hydrosilylation reactions, thus demonstrating that this ligand class represents a very useful addition to the growing number of non-cyclopentadienyl ligands in organo rare earth metal and organolanthanide chemistry. 
Table 1. Metal-nitrogen bond lengths $[\AA]$ and M-N-C angles $\left[^{\circ}\right]$ for mono(imidazolin-2iminato) complexes.

\begin{tabular}{lll}
\hline & $\mathrm{M}-\mathrm{N} 1$ & $\mathrm{M}-\mathrm{N} 1-\mathrm{C} 1$ \\
\hline $\mathbf{2 a}(\mathrm{M}=\mathrm{Sc})$ & $1.963(2)$ & $174.5(2)$ \\
$\mathbf{2 b}(\mathrm{M}=\mathrm{Y})$ & $2.1278(18)$ & $174.35(16)$ \\
$\mathbf{2 c}(\mathrm{M}=\mathrm{Lu})$ & $2.091(3)$ & $174.2(2)$ \\
$\mathbf{2 d}(\mathrm{M}=\mathrm{Gd})$ & $2.153(3)$ & $175.5(3)$ \\
$\mathbf{3}(\mathrm{M}=\mathrm{Y})$ & $2.115(2)$ & 180.0 \\
$\mathbf{4 a}(\mathrm{M}=\mathrm{Sc})$ & $1.9520(18)$ & $178.90(18)$ \\
$\mathbf{4 b}(\mathrm{M}=\mathrm{Y})$ & $2.1255(13)$ & $176.85(12)$ \\
$\mathbf{4 c}(\mathrm{M}=\mathrm{Lu})$ & $2.089(3)$ & $176.4(2)$ \\
$\mathbf{4 d}(\mathrm{M}=\mathrm{Gd})$ & $2.1643(13)$ & $170.85(12)$ \\
$\mathbf{5 b}(\mathrm{M}=\mathrm{Y})$ & $2.135(2)$ & $166.08(17)$ \\
$\mathbf{5 d}(\mathrm{M}=\mathrm{Gd})$ & $2.172(5) / 2.180(5)$ & $164.9(4) / 166.1(5)$ \\
$\mathbf{6 c}(\mathrm{M}=\mathrm{Lu})$ & $2.0752(18)$ & $178.27(16)$ \\
$\mathbf{7 a}(\mathrm{M}=\mathrm{Sc})$ & $1.9575(10)$ & $169.72(9)$ \\
$\mathbf{7 c}(\mathrm{M}=\mathrm{Lu})$ & $2.0697(18)$ & $171.24(17)$ \\
$\mathbf{8}(\mathrm{M}=\mathrm{Gd})$ & $2.2388(13)$ & $174.57(11)$ \\
$\mathbf{9 a}(\mathrm{M}=\mathrm{Sc})$ & $1.9466(12)$ & $172.45(10)$ \\
$\mathbf{9 b}(\mathrm{M}=\mathrm{Y})$ & $2.0829(14)$ & $175.11(13)$ \\
$\mathbf{1 0 a}(\mathrm{M}=\mathrm{Sc})$ & $1.9441(7)$ & $151.5(15)$ \\
$\mathbf{1 0 b}(\mathrm{M}=\mathrm{Y})$ & $2.097(2)$ & $162.27(18)$ \\
$\mathbf{1 0 c}(\mathrm{M}=\mathrm{Lu})$ & $2.068(2)$ & $162.4(2)$ \\
$\mathbf{1 1 a}(\mathrm{M}=\mathrm{Sc})$ & $1.982(2) / 1.965(2)$ & $166.6(2) / 168.1(2)$ \\
$\mathbf{1 1 b}(\mathrm{M}=\mathrm{Y})$ & $2.163(2)$ & $163.51(19)$ \\
$\mathbf{1 1 c}(\mathrm{M}=\mathrm{Lu})$ & $2.122(2)$ & $166.7(2)$ \\
$\mathbf{1 1 d}(\mathrm{M}=\mathrm{Gd})$ & $2.191(2)$ & $162.89(19)$ \\
\hline & & \\
\hline & &
\end{tabular}


Table 2. Metal-nitrogen bond lengths $[\AA]$ and M-N-C angles $\left[{ }^{\circ}\right]$ for bis(imidazolin-2-iminato) complexes.

\begin{tabular}{lllll}
\hline & M-N1 & M-N4 & M-N1-C1 & M-N4-C28 \\
\hline $\mathbf{1 4 a}(\mathrm{M}=\mathrm{Sc})$ & $2.003(2)$ & $2.014(2)$ & $178.2(2)$ & $176.9(2)$ \\
$\mathbf{1 4 b}(\mathrm{M}=\mathrm{Y})$ & $2.166(2)$ & $2.166(2)$ & $172.6(2)$ & $172.5(2)$ \\
$\mathbf{1 4 c}(\mathrm{M}=\mathrm{Lu})$ & $2.124(4)$ & $2.137(4)$ & $178.1(4)$ & $175.8(4)$ \\
$\mathbf{1 5}(\mathrm{M}=\mathrm{Yb})$ & $2.109(3)$ & $2.104(3)$ & $179.1(3)$ & $177.6(3)$ \\
$\mathbf{1 6 b}(\mathrm{M}=\mathrm{Y})$ & $2.1701(15)$ & $2.1993(15)$ & $179.55(14)$ & $169.35(14)$ \\
$\mathbf{1 6 c}(\mathrm{M}=\mathrm{Lu})$ & $2.1333(17)$ & $2.1636(16)$ & $179.24(17)$ & $169.30(16)$ \\
\hline
\end{tabular}

Table 3. Metal-nitrogen bond lengths $[\AA]$ for tris(imidazolin-2-iminato) complexes.

\begin{tabular}{lll}
\hline & $\mathrm{M} \mathrm{N}_{\text {terminal }}$ & ${\mathrm{M}-\mathrm{N}_{\text {bridging }}}$ \\
\hline $\mathbf{1 7 a}(\mathrm{M}=\mathrm{Sc})$ & $1.984(2)$ & $2.122(2)$ \\
& $2.004(2)$ & $2.143(2)$ \\
$\mathbf{1 7 b}(\mathrm{M}=\mathrm{Y})$ & $2.167(3)$ & $2.355(3)$ \\
& $2.164(3)$ & $2.335(3)$ \\
& $2.167(4)$ & \\
& $2.161(4)$ & \\
$\mathbf{1 7 c}(\mathrm{M}=\mathrm{Lu})$ & $2.1247(14)$ & $2.2519(13)$ \\
& $2.1380(14)$ & $2.2921(12)$ \\
& $2.1211(13)$ & \\
$\mathbf{1 8}(\mathrm{M}=\mathrm{Y})$ & $2.1102(14)$ & \\
& $2.2066(16)$ & \\
& $2.2122(17)$ & \\
& $2.1625(16)$ & \\
\hline
\end{tabular}




\section{References and Footnotes}

[1] a) T. J. Keely, P. L. Pauson, Nature 1951, 168, 1039; b) S. Miller, J. A. Tebboth, J. F. Tremaine, J. Chem. Soc. 1952, 632.

[2] E. O. Fischer, W. Pfab, Z. Naturforsch. 1952, 7b, 377.

[3] G. Wilkinson, M. Rosenblum, M. C. Whiting, R. B. Woodward, J. Am. Chem. Soc. 1952, 74, 2125.

[4] Special Issue: 50th Anniversary of the Discovery of Ferrocene (Ed. R. D. Adams), J. Organomet. Chem. 2001, 637-639, 1.

[5] H. Werner, Landmarks in Organo-Transition Metal Chemistry, Springer, New York 2009.

[6] a) G. Wilkinson, J. M. Birmingham, J. Am. Chem. Soc. 1954, 76, 6210; b) J. M. Birmingham, G. Wilkinson, J. Am. Chem. Soc. 1956, 78, 42.

[7] H. Schumann, J. A. Meese-Marktscheffel, L. Esser, Chem. Rev. 1995, 95, 865.

[8] C. J. Schaverien, Adv. Organomet. Chem. 1994, 36, 283.

[9] a) W. J. Evans, Polyhedron 1987, 6, 803; b) W. J. Evans, B. L. Davis, Chem. Rev. 2002, 102, 2119; c) W. J. Evans, J. Organomet. Chem. 2002, 647, 2; d) W. J. Evans, Inorg. Chem. 2007, 46, 3435.

[10] S. Arndt, J. Okuda, Chem. Rev. 2002, 102, 1953.

[11] W. A. Herrmann, R. Anwander, Topics Curr. Chem. 1996, 179, 1.

[12] M. N. Bochkarev, Chem. Rev. 2002, 102, 2089.

[13] G. A. Molander, J. A. C. Romero, Chem. Rev. 2002, 102, 2161.

[14] F. T. Edelmann, Comprehensive Organometallic Chemistry III (Elsevier), 2007, 4, 1.

[15] a) F. T. Edelmann, D. M. M. Freckmann, H. Schumann, Chem. Rev. 2002, 102, 1851;

b) F. T. Edelmann, Angew. Chem. 1995, 107, 2647; Angew. Chem. Int. Ed. Engl. 1995, 
34, 2466; c) R. Kempe, Angew. Chem. 2000, 112, 478; Angew. Chem. Int. Ed. 2000, $39,468$.

[16] W. E. Piers, D. J. H. Emslie, Coord. Chem. Rev. 2002, 233-234, 131.

[17] S. Cotton, Lanthanide and Actinide Chemistry, J. Wiley \& Sons Ltd., the Atrium, Southern Gate, Chichester, 2006.

[18] R. D. Shannon, Acta Cryst. 1976, A32, 751.

[19] a) R. Anwander, Topics Curr. Chem. 1996, 179, 149; b) R. C. Mehrotra, A. Singh, U. M. Tripathi, Chem. Rev. 1991, 91, 1287; c) T. Boyle, L. A. Ottly, Chem. Rev. 2008, $108,1896$.

[20] R. Anwander, Topics Curr. Chem. 1996, 179, 33.

[21] K. Dehnicke, A. Greiner, Angew. Chem. 2003, 115, 1378; Angew. Chem. Int. Ed. Engl. 2003, 42, 1340.

[22] a) H. Tsukube, S. Shinoda, H. Tamiaki, Coord. Chem. Rev. 2002, 226, 227; b) S. Kaizaki, Coord. Chem. Rev. 2006, 250, 1804; c) G. G. Condorelli, G. Malandrino, I. L. Fagala, Coord. Chem. Rev. 2007, 1931.

[23] a) L. Bourget-Merle, M. F. Lappert, J. R. Severn, Chem. Rev. 2002, 102, 3031; b) P. B. Hitchcock, A. V. Khvostov, M. F. Lappert, A. V. Protchenko, Dalton Trans. 2009, 2383; c) M. F. Lappert, J. Organomet. Chem. 2000, 600, 144; d) P. M. Zeimentz, S. Arndt, B. R. Elvidge, J. Okuda, Chem. Rev. 2006, 106, 2404; e) D. V. Vitanova, F. Hampel, K. C. Hultzsch, J. Organomet. Chem. 2005, 690, 5182; f) B. B. Lazarov, F. Hampel, K. C. Hultzsch, Z. Anorg. Allg. Chem. 2007, 633, 2367; g) Y. Yao, Z. Zhang, H. Peng, Y. Zhang, Q. Shen, J. Lin, Inorg. Chem. 2006, 45, 2175; h) L. F. SanchezBarba, D. L. Hughes, S. M. Humphrey, M. Bochmann, Organometallics 2005, 24, 3792; i) L. W. M. Lee, W. E. Piers, M. R. J. Elsegood, W. Clegg, M. Parvez, Organometallics 1999, 18, 2947; j) P. G. Hayes, W. E. Piers, M. Parvez, Organometallics 2005, 24, 1173. 
[24] (a) F. T. Edelmann, Adv. Organomet. Chem. 2008, 57, 183; b) F. T. Edelmann, Chem. Soc. Rev. 2009, 38, 2253.

[25] a) M. R. Bürgstein, H. Berberich, P. W. Roesky, Organometallics 1998, 17, 1452; b) N. Meyer, A. Zulys, P. W. Roesky, Organometallics 2006, 25, 4179; c) N. Meyer, P. W. Roesky, Dalton Trans. 2007, 2652; d) N. Meyer, P. W. Roesky, Organometallics 2009, 28, 306.

[26] a) R. Kempe, Eur. J. Inorg Chem. 2003, 2003, 791; b) R. Kempe, H. Noss, T. Irrgang, J. Organomet. Chem. 2002, 647, 12; c) G. Glatz, S. Demeshko, G. Motz, R. Kempe, Eur. J. Inorg. Chem. 2009, 1385; d) N. M. Scott, T. Schareina, O. Tok, R. Kempe, Eur. J. Inorg. Chem. 2004, 3297; e) N. M. Scott, R. Kempe, Eur. J. Inorg. Chem. 2005, 1319.

[27] a) M. T. Gamer, M. Rastätter, P. W. Roesky, A. Steffens, M. Glanz, Chem. Eur. J. 2005, 11, 3165; b) M. T. Gamer, P. W. Roesky, I. Palard, M. Le Hellaye, S. M. Guillaume, Organometallics 2007, 26, 651; c) T. K.; Panda, M. T. Gamer, P. W. Roesky, Inorg. Chem. 2006, 45, 910; d) T. K. Panda, A. Zulys, M. T. Gamer, P. W. Roesky, Organometallics 2005, 24, 2197; e) A. Zulys, T. K. Panda, M. T. Gamer, P. W. Roesky, Chem. Commun. 2004, 2584.

[28] (a) M. Wedler, F. Kösel, U. Pieper, D. Stalke, F. Edelmann, H.-D. Amberger, Chem. Ber. 1992, 125, 2171; b) F. T. Edelmann, Topics Curr. Chem. 1996, 179, 113. c) M. R. G. Skinner, P. Mountford, J. Chem. Soc., Dalton Trans. 2002, 1694; d) S. Yao, H.-S. Chan, C.-K. Lam, H. K. Lee, Inorg. Chem. 2009, 48, 9936.

[29] a) Roesky, P. W. Heteroatom Chem. 2002, 13, 514; b) P. P. Power, J. Organomet. Chem. 2004, 689, 3904; c) Z. Fei, P. J. Dyson, Coord. Chem. Rev. 2005, 249, 2056.

[30] N. Kuhn, M. Göhner, M. Grathwohl, J. Wiethoff, G. Frenking, Y. Z. Chen, Anorg. Allg. Chem. 2003, 629, 793.

[31] N. Kuhn, R. Fawzi, M. Steimann, J. Wiethoff, Z. Anorg. Allg. Chem. 1997, 623, 769. 
[32] N. Kuhn, R. Fawzi, M. Steimann, J. Wiethoff, D. Bläser, R. Boese, Z. Naturforsch. 1995, 50, 1779.

[33] M. Tamm, S. Randoll, T. Bannenberg, E. Herdtweck, Chem. Commun. 2004, 876.

[34] M. Tamm, S. Beer, E. Herdtweck, Z. Naturforsch. 2004, 59b, 1497.

[35] M. Tamm, S. Randoll, E. Herdtweck, N. Kleigrewe, G. Kehr, G. Erker, B. Rieger, Dalton Trans. 2006, 459.

[36] M. Tamm, S. Beer, C. G. Hrib, P. G. Jones, K. Brandhorst, J. Grunenberg, Angew. Chem. 2007, 119, 9047; Angew. Chem. Int. Ed. 2007, 46, 8890.

[37] M. Tamm, S. Beer, K. Brandhorst, J. Grunenberg, C. G. Hrib, P. G. Jones, Org. Lett. 2008, $10,981$.

[38] S. H. Stelzig, M. Tamm, R. M. Waymouth, J. Polym. Sci. Part A., Polym. Chem. 2008, 46,6064 .

[39] M. Tamm, S. Beer, K. Brandhorst, C. G. Hrib, X. Wu, B. Haberlag, J. Grunenberg, P. G. Jones, Organometallics 2009, 28, 1534.

[40] M. Tamm, T. K. Panda, C. G. Hrib, P. G. Jones, J. Jenter, P. W. Roesky, Eur. J. Inorg. Chem. 2008, 4270.

[41] T. K. Panda, S. Randoll, C. G. Hrib, P. G. Jones, T. Bannenberg, M. Tamm, Chem. Commun. 2007, 5007.

[42] T. K. Panda, A. G. Trambitas, T. Bannenberg, C. G. Hrib, S. Randoll, P. G. Jones, M. Tamm, Inorg. Chem. 2009, 48, 5462.

[43] M. Tamm, A. G. Trambitas, T. K. Panda, T. Bannenberg, C. G. Hrib, C. G. Daniliuc, P. G. Jones, J. Jenter, P. W. Roesky, Inorg. Chem. 2010, 49, 2435.

[44] K. Dehnicke, J. Strähle, Polyhedron 1989, 8, 707.

[45] K. Dehnicke, M. Krieger, W. Massa, Coord. Chem. Rev. 1999, 182, 19.

[46] K. Dehnicke, F. Wellerm, Coord. Chem. Rev. 1997, 158, 103.

[47] M. Tamm, D. Petrovic, S. Randoll, S. Beer, T. Bannenberg, P. G. Jones, J. Grunenberg, Org. Biomol. Chem. 2007, 5, 523. 
[48] J. Scott, F. Basuli, A. R. Fout, J. C. Huffman, D. J. Mindiola, Angew. Chem. 2008, 120, 8630; Angew. Chem. Int. Ed. 2008, 47, 8502.

[49] a) L. K. Knight, W. E. Piers, P. Fleurat-Lessard, M. Parvez, R. McDonald, Organometallics 2004, 23, 2087; b) L. K. Knight, W. E. Piers, R. McDonald, Organometallics 2006, 25, 3289.

[50] D. Cui, M. Nishiura, Z. Hou, Angew. Chem. 2005, 117, 981; Angew. Chem. Int. Ed. 2005, 44, 959 .

[51] a) T. Gröb, G. Seybert, W. Massa, K. Harms, K. Dehnicke, Z. Anorg. Allg. Chem. 2000, 626, 1361; b) S. Anfang, T. Gröb, K. Harms, G. Seybert, W. Massa, A. Greiner, K. Dehnicke, Z. Anorg. Allg. Chem. 1999, 625, 1853; c) S. Anfang, K. Harms, F. Weller, O. Borgmeier, H. Lueken, H. Schilder; K. Dehnicke, Z. Anorg. Allg. Chem. 1998, 624, 159.

[52] M. Nishiura, Z. Hou, Y. Wakatsuki, T. Yamaki, T. Miyamoto, J. Am. Chem. Soc. 2003, 125, 1184 .

[53] S. A. A. Shah, H. Dorn, H. W. Roesky, P. Lubini, H.-G. Schmidt, Inorg. Chem. 1997, $36,1102$.

[54] M. Tamm, A. G. Trambitas, C. Hrib, P. G. Jones, Terrae Rarae 2009, 03, 1.

[55] a) X. Li, J. Baldamus, Z. Hou, Angew. Chem. 2005, 117, 984; Angew. Chem. Int. Ed. 2005, 44, 962; b) Y. Luo, M. Nishiura, Z. Hou, J. Organomet. Chem. 2007, 692, 536; c) B. R. Elvidge, S. Arndt, T. P. Spaniol, J. Okuda, Dalton Trans. 2006, 890; d) R. G. Howe, C. S. Tredget, S. C. Lawrence, S. Subongkoj, A. R. Cowley, P. Mountford, Chem. Commun. 2006, 223; e) A. Lara-Sanchez, A. Rodriguez, D. L. Hughes, M. Schormann, M. Bochmann J. Organomet. Chem. 2002, 663, 63 ; f) J. Hitzbleck, J. Okuda, Z. Anorg. Allg. Chem. 2006, 632, 1947; g) S. Li, W. Miao, T. Tang, D. Cui, X. Chen, X. Jing, J. Organomet. Chem 2007, 692, 4943; h) B. Wang, D. Cui, K. Lv, Macromolecules 2008, 41, 1983; i) S. Ge, A. Meetsma, B. Hessen, Organometallics 
2007, 26, 5278; j) S. C. Marinescu, T. Agapie, M. W. Day, J. E. Bercaw, Organometallics 2007, 26, 1178.

[56] a) B. Wang, D. Wang, D. Cui, W. Gao, T. Tang, X. Chen, X. Jing, Organometallics 2007, 26, 3167; b) J. Hitzbleck, J. Okuda, Organometallics 2007, 26, 3227; c) Y. Yang, B. Liu, K. Lv, W. Gao, D. Cui, X. Chen, X. Jing, Organometallics, 2007, 26, 4575; d) R.G. Howe, C. S. Tredget, S. C. Lawrence, S. Subongkoj, A. R. Cowley, P. Mountford, Chem. Commun. 2006, 223; e) B. Wang, D. Cui, K. Lv, Macromolecules 2008, 41, 1983; f) T. M. Cameron, J. C. Gordon, R. Michalczyk, B. L. Scott, Chem. Commun. 2003, 2282.

[57] a) B. Liu, Y. Yang, D. Cui, T. Tang, X. Chen, X. Jing, Dalton Trans. 2007, 4252; b) B. Liu, D. Cui, J. Ma, X. Chen, X Jing, Chem. Eur. J. 2007, 13, 834; c) H. Schumann, D. M. M. Freckmann, S. Schutte, S. Dechert, M. Z. Hummert, Anorg. Allg. Chem. 2007, 633, 888; d) L. Zhang, T. Suzuki, Y. Luo, M. Nishiura, Z. Hou, Angew. Chem. 2007, 119, 1941; Angew. Chem. Int. Ed. 2007, 46, 1909; e) K. A. Rufanov, A. R. Petrov, V. V. Kotov, F. Laquai, J. Sundermeyer, Eur. J. Inorg. Chem. 2005, 3805; f) J. D. Masuda, K. C. Jantunen, O. V. Ozerov, K. J. T. Noonan, D. P. Gates, B. L. Scott, J. L. Kiplinger, J. Am. Chem. Soc. 2008, 130, 2408; g) W. J. Evans, R. N. R. Broomhall-Dillard, J. W. Ziller, J. Organomet. Chem. 1998, 569, 89; h) S. Arndt, T. P. Spaniol, J. Okuda, Organometallics 2003, 22, 775; i) T. M. Cameron, J. C. Gordon, B. L. Scott, Organometallics 2004, 23, 2995; j) J. D. Masuda, K. C. Jantunen, B. L. Scott, J. L. Kiplinger, Organometallics 2008, 27, 1299; k) K. C. Jantunen, B. L. Scott, J. C. Gordon, J. L. Kiplinger, Organometallics 2007, 26, 2777.

[58] a) S. Bambirra, E. Otten, D. van Leusen, A. Meetsma, B. Hessen, Z. Anorg. Allg. Chem. 2006, 632, 1950; b) S. Bambirra, E. Otten, D. van Leusen, A. Meetsma, B. Hessen, J. H. Teuben, Chem. Commun. 2001, 637; c) S. Bambirra, E. Otten, D. van Leusen, A. Meetsma, B. Hessen, J. H. Teuben, Chem. Commun. 2003, 522; d) S. Ge, A. Meetsma, B. Hessen, B. Sergio, Chem. Commun. 2006, 3320; e) D. J. H. Emslie, 
W. E. Piers, M. Parvez, R. McDonald, Organometallics 2002, 21, 4226; f) P. G. Hayes, G. C. Welch, D. J. H. Emslie, C. L. Noack, E. P. Warren, M. Parvez, Organometallics 2003, 22, 1577; g) S. Bambirra, S. J. Boot, D. van Leusen, A. Meetsma, B. Hessen, Organometallics 2004, 23, 1891; h) S. Bambirra, A. Meetsma, B. Hessen, Organometallics 2006, 25, 3486; i) S. Bambirra, D. van Leusen, C. G. J. Tazelaar, A. Meetsma, B. Hessen, Organometallics 2007, 26, 1014.

[59] S. Arndt, J. Okuda, Adv. Synth. Catal. 2005, 347, 339.

[60] a) C. J. Schaverien, Organometallics 1994, 13, 69; b) R. E. White, T. P. Hanusa, Organometallics 2006, 25, 5621.

[61] a) H. C. Aspinall, D. C. Bradley, M. B. Hursthouse, K. D. Sales, N. P. C. Walker, B. Hussain, Dalton Trans. 1989, 623; b) W. A. Hermann, R. Anwander, F. C. Munck, W. Scherer, V. Dufaud, N. W. Huber, G. R. J. Artus, Z. Naturforschung 1994, 49b, 1789; c) M. Karl, K. Harms, K. Dehnicke, Z. Anorg. Allg. Chem. 1999, 625, 1774; d) M. G. Klimpel, H. W. Görlitzer, M. Tafipolsy, M. Spiegler, W. Scherer, R. Anwander, J. Organomet. Chem. 2002, 647, 236; e) M. Niemeyer, Inorg. Chem. 2006, 45, 9085; f) M. Rastätter, A.; Zulys, Roesky, P. W. Chem. Commun. 2006, 874. (g) M. Rastätter, A. Zylus, P. W. Roesky, Chem. Eur. J. 2007, 13, 3606; h) C. Döring, R. Kempe, Eur. J. Inorg. Chem. 2009, 412.

[62] a) W. J Evans, T. A. Ulibarri, J. W. Ziller, Organometallics 1991, 10, 134; b) A. Madel, J. Magull, Z. Anorg. Allg. Chem. 1996, 622, 1913; c) W. E. Piers, L. W. M. Lee, M. Parvez, M. R. J. Elsegood, W. Clegg, Organometallics 1999, 18, 2947; d) S. Bambirra, M. J. R. Brandsma, E. A. C. Brussee, A. Meetsma, B. Hessen, J. H. Teuben, Organometallics 2000, 19, 3197; e) P. G. Hayes, W. E. Piers, L. W. M. Lee, L. K. Knight, M. Parvez, M. R. J. Elsegood, W. Clegg, Organometallics 2001, 20, 2533; f) A. G. Avent, G. N. Cloke, B. R. Elvidge, P. B. Hitchcock, Dalton Trans. 2004, 1083; g) S. Bambirra, A. Meetsma, B. Hessen, Organometallics 2006, 25, 3454; h) J. 
Hitzbleck, K. Beckerle, J. Okuda, J. Organomet. Chem. 2007, 692, 4702; i) C. T. Carver, M. J. Montreal, P. L. Diaconescu, Organometallics 2008, 27, 363.

[63] N. Meyer, P. W. Roesky, S. Bambirra, A. Meetsma, B. Hessen, K. Salin, J. Takas, Organometallics 2008, 27, 1501.

[64] These structures are closely related to chiral three-legged half-sandwich transition metal complexes of the type $\left[(\mathrm{Cp}) \mathrm{ML}^{1} \mathrm{~L}^{2} \mathrm{~L}^{3}\right]$, see: a) H. Brunner, Angew. Chem. 1999, 111, 1248; Angew. Chem. Int. Ed. 1999, 38, 1194; b) H. Brunner, Eur. J. Inorg. Chem. 2001, 905; c) H. Brunner, T. Tsuno, Acc. Chem. Res. 2009, 42, 1501.

[65] M. F. Hawthorne, D. C. Young, P. A. Wegner, J. Am. Chem. Soc. 1965, 87, 1818.

[66] M. F. Hawthorne, D. C. Young, T. D. Andrews, D. V. Howe, R. L. Pilling, A. D. Pitts, M. Reintjes, L. F. Jr. Warren, P. A. Wegner, J. Am. Chem. Soc. 1968, 90, 879.

[67] M. J. Manning, C. B. Knobler, M. F. Hawthorne, J. Am. Chem. Soc. 1988, 110, 4458.

[68] Z. Xie, Acc. Chem. Res. 2003, 36, 1.

[69] K. Chui, T. C. W. Mak, W. H. Lan, Z. Lin, Z. Xie, J. Am. Chem. Soc. 2000, 122, 5758.

[70] L. Deng, H.-S. Chan, Z. Xie, Angew. Chem. 2005, 117, 2166; Angew. Chem. Int. Ed. 2005, 44, 2128.

[71] L. Deng, H.-S. Chan, Z. Xie, J. Am. Chem. Soc. 2006, 128, 5219.

[72] H. Shen, H.-S. Chan, Z. Xie, J. Am. Chem. Soc. 2007, 129, 12934.

[73] M.-S. Cheung, H.-S. Chan, Z. Xie, Dalton Trans. 2005, 2375.

[74] K. Chui, Q. Yang, T. C. W. Mak, W. H. Lam, Z. Lin, Z. Xie, J. Am. Chem. Soc. 2000, $122,5758$.

[75] H. Shen, H.-S. Chan, Z. Xie, J. Am. Chem. Soc. 2007, 129, 12934.

[76] G. Zi, H.-W. Li, Z Xie, Organometallics 2002, 21, 3464.

[77] M.-S. Cheung, H.-S. Chan, Z. Xie, Organometallics 2004, 23, 517.

[78] M.-S. Cheung, H.-S. Chan, Z. Xie, Organometallics 2005, 24, 4207.

[79] Z. Xie, Z. Liu, K.-Y. Chiu, F. Xue, T.C. W. Mak, Organometallics 1997, 16, 2460. 
[80] A. G. Trambitas, Z. Xie, M. Tamm, unbublished results.

[81] F. T. Edelmann, New J. Chem. 1995, 19, 535.

[82] G. R. Giesbrecht, J. C. Gordon, Dalton Trans. 2004, 2387.

[83] S. C. Dunn, N. Hazari, N. M. Jones, A. G. Moody, A. J. Blake, A. R. Cowley, J. C. Green, P. Mountford, Chem. Eur. J. 2005, 11, 2111.

[84] S. C. Dunn, N. Hazari, A. R. Cowley, J. C. Green, P. Mountford, Organometallics 2006, 25, 1755.

[85] A. G. Trambitas, C. G. Daniliuc, P. G. Jones, M. Tamm, unpublished results.

[86] Y. Yao, Y. Zhang, Z. Zhang, Q. Shen, K. Yu, Organometallics 2003, 22, 2876.-

[87] T. Gröb, G. Seybert, W. Massa, F. Weller, R. Paliswami, A. Greiner, K. Dehnicke, Angew. Chem. 2000, 112, 4542; Angew. Chem Int. Ed. 2000, 39, 4373.

[88] T. K. Panda, C. G. Hrib, P. G. Jones, M. Tamm, J. Organomet. Chem. 2010, submitted.

[89] R. D. Rogers, J. L. Atwood, A. Emad, D. J. Sikora, M. D. Rausch, J. Organomet. Chem. 1981, 216, 383.

[90] a) N. Kuhn, M. Grathwohl, M. Steimann, G. Henkel, Z. Naturforsch. B 1998, 53, 997,

b) N. Kuhn, M. Grathwohl, C. Nachtigal, M. Steimann, Z. Naturforsch. B 2001, 56, 704.

[91] a) D. Petrovic, T. Glöge, T. Bannenberg, C. G. Hrib, S. Randoll, P. G. Jones, M. Tamm, Eur. J. Inorg. Chem. 2007, 3472 ; b) D. Petrovic, C. G. Hrib, S. Randoll, P. G. Jones, M. Tamm, Organometallics 2008, 27, 778 ; c) T. Glöge, D. Petrovic, C. Hrib, P. G. Jones, M. Tamm, Eur. J. Inorg. Chem. 2009, 4538.

[92] a) D. Petrovic, T. Bannenberg, S. Randoll, P. G. Jones, M. Tamm, Dalton Trans. 2007, 2812; b) D. Petrovic, L. M. R. Hill, P. G. Jones, W. B. Tolman, M. Tamm, Dalton Trans. 2008, 887.

[93] S. Randoll, P. G. Jones, M. Tamm, Organometallics 2008, 27, 3232. 
[94] T. K. Panda, C. G. Hrib, P. G. Jones, J. Jenter, P. W. Roesky, M. Tamm, Eur. J. Inorg. Chem. 2008, 4270.

[95] A. L. McKnight, R. M. Waymouth, Chem. Rev. 1998, 98, 2587.

[96] W.-X. Zhang, M. Nishiura, Z. Hou, Chem. Eur. J. 2007, 13, 4037.

[97] K. C. Hultzsch, P. Voth, K. Beckerle, T. P. Spaniol, J. Okuda, Organometallics 2000, $19,228$.

[98] M. Nishiura, Z. Hou, Y. Wakatsuki, T. Yamaki, T. Miyamoto, J. Am. Chem. Soc. 2003, $125,1184$.

[99] S.-A. Filimon, D. Petrovic, M. Tamm, unpublished results.

[100] T. K. Panda, D. Petrovic, T. Bannenberg, C. G. Hrib, P. G. Jones, M. Tamm, Inorg. Chim. Acta 2008, 361, 2236.

[101] W.T. Klooster, L. Brammer, C.J. Schaverien, P. H. M. Budzelaar, J. Am. Chem. Soc. 1999, $121,1381$.

[102] W. Scherer, G. S. McGrady, Angew. Chem. 2004, 116, 1816; Angew. Chem. Int. Ed. 2004, 43, 1782.

[103] P. L. Watson, G. W. Parshall, Acc. Chem. Res. 2002, 18, 51.

[104] a) G. A. Molander, E. D. Dowdy, Top. Organomet. Chem. 1999, 119; b) G. A. Molander, Pure Applied Chem 2000, 72, 1767; c) M. Shibaski, N. Yoshikawa, Chem Rev. 2002, 102, 2187; d) K. Mikami, M. Terada, H. Matzuzawa, Angew. Chem. 2002, 114, 3704; Angew. Chem. Int. Ed. 2002, 41, 3554; e) Z. Hou, Wakatsuki, Y. Coord. Chem. Rev 2002, 231, 1; f) Y. Nakayama, H. Yasuda, J. Organomet. Chem. 2004, 689, 4489; g) Z. Hou, Y. Luo, Y. Li, J. Organomet. Chem. 2006, 691, 3114.

[105] Hong, S.; Marks, T. J. Acc. Chem. Res. 2004, 37, 673.

[106] T. K. Panda, M. Tamm, unpublished results.

[107] a) T. J. Marks, J. Am. Chem. Soc. 1989, 111, 4108; b) M. R. Gagne, C. Stern, T. J Marks, J. Am. Chem. Soc. 1992, 114, 275; c) P. W. Roesky, C. L. Stern, T. J. Marks, Organometallics 1997, 16, 4705; d) Y. Li, T. J. Marks, J. Am. Chem. Soc. 1998, 120, 
1757; e) V. M.; Arrandondo, F. E. McDonald, T. J. Marks, J. Am. Chem. Soc. 1998, 120, 4871; f) V. M. Arrandondo, S. Tian, F. E. McDonald, T. J. Marks, J. Am. Chem. Soc. 1999, 121, 3633; g) M. R. Douglas, T. J. Marks, J. Am. Chem. Soc. 2000, 122, 1824; h) M. R. Douglas, C. Stern, T. J. Marks, J. Am. Chem. Soc. 2001, 123, 10221; i) S. Hong, T. J. Marks, J. Am. Chem. Soc. 2002, 124, 7886; j) J.-S. Ryu, T. J. Marks, J. Am. Chem. Soc. 2003, 125, 12584.

[108] a) M. R. Bürgstein, H. Berberich, P. W. Roesky, Organometallics 1998, 17, 1452; b) N. Meyer, A. Zulys, P. W. Roesky, Organometallics 2006, 25, 4179; c) N. Meyer, P. W. Roesky, Dalton Trans. 2007, 2652; d) N. Meyer, P. W. Roesky, Organometallics 2009, 28, 306; e) M. Rastätter, A. Zylus, P. W. Roesky, Chem. Eur. J. 2007, 13, 3606. f) P. W. Roesky, T. E. Müller, Angew Chem. Int. Ed. 2003, 42, 2708; g) S. Datta, M. T. Gamer, P. W. Roesky, Organometallics 2008, 27, 1207.

[109] C. Döring, R. Kempe, Eur. J. Inorg. Chem. 2009, 412.

[110] a) D. Riegert, J. Collin, A. Meddour, E. Schulz, A. Trifanov, J. Organomet. Chem. 2005, 71, 2514; b) I. Ailland, D. Lynbov, J. Collin, R. Guillat, J. Hanndouche, E. Schulz, A. Trifonov, Organometallics, 2008, 27, 5929; c) Y. K. Kim, T. Livinghouse, Angew. Chem. 2002, 114, 4344; Angew. Chem. Int. Ed. 2002, 41, 3645; d) Y. K. Kim, T. Livinghouse, Y. Horino, J. Am. Chem. Soc. 2003, 125, 9560; e) Y. K. Kim, T. Livinghouse, Y. Horino, J. Am. Chem. Soc. 2003, 125, 9560.

[111] a) K. C. Hultzsch, D. V. Gribkov, F. Hampel, J. Organomet. Chem. 2005, 690, 4441; b) K. C. Hultzsch, D. V. Gribkov, F. Hampel, Chem. Eur. J. 2003, 9, 4796; c) K. C. Hultzsch, D. V. Gribkov, Chem. Commun. 2004, 730; d) K. C. Hultzsch, F. Hampel, T. Wagner, Organometallics 2004, 23, 2601.

[112] a) R. M. Beesley, C. K. Inglod, J. F. Thorpe, J. Chem. Soc. 1915, 107, 1080; b) C. K. Ingold, J. Chem. Soc. 1921, 119, 305; c) A. J. Kirby, Adv. Phys. Org. Chem. 1980, 17, 183; d) M. E. Jung, J. Gervay, J Am. Chem. Soc. 1991, 113, 224.

[113] Y. Li, T. J. Marks, J. Am. Chem. Soc. 1996, 118, 9295. 
[114] P.-F. Fu, L. Brard, Y. Li, T. J. Marks, J. Am. Chem. Soc. 1995, 117, 7157.

[115] S. Ge, A. Meetsma, B. Hessen, Organometallics 2008, 27, 3131. 